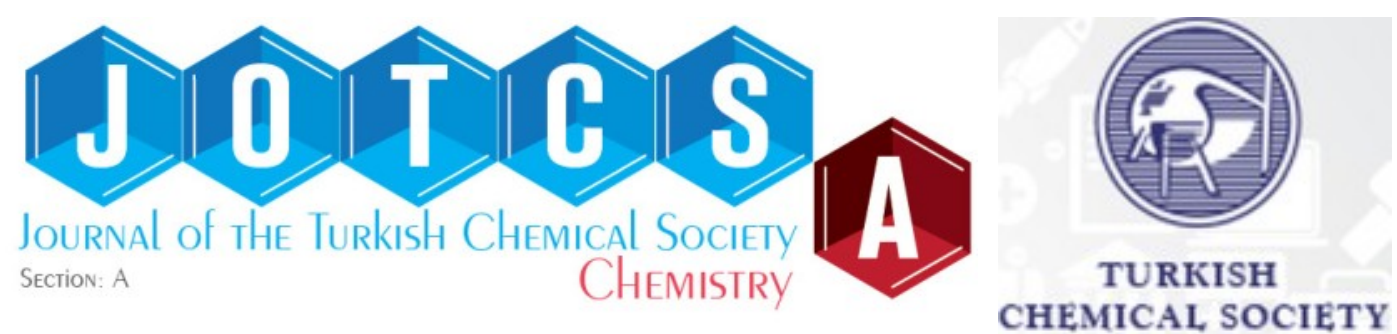

\title{
Synthesis and Characterization of Azobenzene Derived from 8- aminoquinoline in Aqueous Media
}

\author{
İdris KARAKAYA ${ }^{1}$ \\ ${ }^{1}$ Department of Chemistry, College of Basic Sciences, Gebze Technical University, 41400 Gebze, Turkey
}

\begin{abstract}
A series of novel 8-(aryldiazenyl)quinolones have been synthesized effectively with excellent yields by using 8-amimoquinoline and a variety of aryldiazonium salts containing electron donating and withdrawing moieties in aqueous media. The structure of the synthesized azo dyes has been characterized by NMR, FTIR, mass spectroscopy, and UV-Vis techniques. The compounds' absorption maxima values are in the range of $427 \mathrm{~nm}$ and $445 \mathrm{~nm}$ due to $\Pi-\Pi^{*}$ charge transfer transition. It can be evaluated that azobenzenes have more absorbance ability in the strong donor systems.
\end{abstract}

Keywords: Azo dye, 8-aminoquinoline, aqueous media, diazonium salt, azobenzene

Submitted: October 20, 2021. Accepted: December 062021.

Cite this: Karakaya İ. Synthesis and Characterization of Azobenzene Derived from 8-aminoquinoline in Aqueous Media. JOTCSA. 2022;9(1):85-114.

DOI: https://doi.org/10.18596/jotcsa.1012453.

*Corresponding author. E-mail: karakaya@gtu.edu.tr.

\section{INTRODUCTION}

Azobenzenes are an important class of organic compounds that are widely used as organic dyes ( 1 , $2)$, protein probes $(3,4)$, chemosensors $(5,6)$, cosmetics (7-9), nanotubes $(10,11)$ and polymers (12-14). Due to the presence of $\mathrm{N}-\mathrm{N}$ linkages, they have been used for pharmacological applications such as antiviral, anti-inflammatory, antimicrobial, antitumor, antidiabetics, and antituberculotic (1525 ). Beyond their potential in these application areas, azo-compounds are mostly used as dyes. Until the late 1800s, all dyes were obtained from natural sources. However, limitation of the natural dye sources led scientists to synthesize dyes with a wide variety of new colors. Azo dyes can be easily prepared by using diazo and coupling components that are generally low-cost materials (26). Due to remarkable stability, light resistance and easy diversification of donor and acceptor groups in the organic compounds, azo dyes are one-step ahead of other dyes (27, 28). Currently, the dyes and pigments market are valued for approximately USD $\$ 33$ billion (29) and keeping the number and production volume about $70 \%$ in mind, azo dyes are the largest class of organic dye around the world (30). Having such a large market share, as a matter of course increases the tendency towards azo dyes.

Quinoline backbones are considered as one of the main classes of heterocyclic chemistry and are found in many natural products, alkaloids, and synthetic molecules (31-33). Quinoline forms the main framework of drugs used clinically in the treatment of many diseases (34). After first discovering chloroquine as an antimalarial drug in 1934, many other analogues were explored such as mefloquine, piperquine, primaquine and amodiaquine (35-39). Also, they are used as antibiotics such as gatifloxacin, moxifloxacin, ciprofloxacin, sparfloxacin, levofloxacin, and norfloxacin (40-42). In addition, due to the formation of stable complexes with many metals, quinolines are known as the best chelating agents (43-48).

In this regard, herein the author reports the simple, efficient synthesis and characterization of 8(aryldiazenyl)quinolines (6a-g) by using 8- 
aminoquinoline (3a) and aryldiazonium salts (5a-g) in aqueous media.

\section{EXPERIMENTAL SECTION}

\section{General considerations}

All the chemicals used were used as received without further purification. IR spectra were recorded on a PerkinElmer Spectrum 100 FT-IR spectrometer. The UV-Visible absorption spectra were carried out with a Shimadzu UV-3600 UV-Vis NIR spectrophotometer in the wavelength range of 200-800 nm. Melting points were determined by using a Stuart melting point apparatus. NMR spectra were recorded on a $500 \mathrm{MHz}$ Varian or Bruker spectrometer. Mass spectra were recorded on a Bruker microflex LT MALDI spectrometer. The spectra are presented in the Supplementary Section at the end of this article.

Synthesis of 8-aminoquinoline (3a)

Under an ice bath, sulfuric acid $(2.0 \mathrm{~mL})$ was added onto quinoline ( $5 \mathrm{mmol}, 1.0$ equiv) then $65 \%$ nitric acid (3.0 equiv) were added dropwise and stirred for $4 \mathrm{~h}$ at $\mathrm{rt}$. The mixture was poured into the ice water and neutralized with $\mathrm{NaOH}$; and then extracted with dichloromethane. After dried over $\mathrm{Na}_{2} \mathrm{SO}_{4}$ and evaporated in vacuo, used next step without purification(49).

Mixture of nitroquinolines (2a-b) and 5\% Pd/C was solved in ethanol and suspension was saturated with hydrogen gas under atmospheric pressure at $40 \mathrm{C}^{\circ}$ until the starting material was consumed. $2 \mathrm{~h}$ later, the mixture was filtered and evaporated. The crude product was purified by silica gel column chromatography, eluting with EtOAc in hexanes to yield the desired 8 -aminoquinoline $\mathbf{3 a}$ is isolated as a brown solid in a yield of $32 \%$ (50).

Obtained as a brown solid (231 mg, 32\%); ${ }^{1} \mathrm{H}$ NMR $\left(500 \mathrm{MHz} \mathrm{CDCl}_{3}\right) \delta 8.71-8.60(\mathrm{~m}, 1 \mathrm{H}), 7.93(\mathrm{~d}, \mathrm{~J}$ $=8.2 \mathrm{~Hz}, 1 \mathrm{H}), 7.29-7.16(\mathrm{~m}, 2 \mathrm{H}), 7.02(\mathrm{~d}, \mathrm{~J}=$ $8.1 \mathrm{~Hz}, 1 \mathrm{H}), 6.80(\mathrm{~d}, J=7.4 \mathrm{~Hz}, 1 \mathrm{H}), 4.89(\mathrm{~s}, 2 \mathrm{H})$.

\section{General Procedure for Synthesis of Aryl Diazonium Salts (5a-g)}

The appropriate aniline $(2.0 \mathrm{mmol})$ and $0.68 \mathrm{~mL}$ $50 \% \mathrm{HBF}_{4}$ aq. in $2.0 \mathrm{~mL}$ distilled water was placed in an ice bath and the temperature was set to $0{ }^{\circ} \mathrm{C}$ then sodium nitrite $(2.0 \mathrm{mmol})$ solution in $1.5 \mathrm{~mL}$ distilled water was added dropwise. The reaction was stirred $30 \mathrm{~min}$. , precipitate was filtered and washed with water $(15 \mathrm{~mL})$ and diethyl ether (15 $\mathrm{mL}$ ). After final filtration, the compound was dried under low pressure and yielded the desired product (51).

4-tert-butylbenzenediazonium (5a)
Obtained as a white solid (416 mg, 84\%); ${ }^{1} \mathrm{H}$ NMR $(500 \mathrm{MHz}, \mathrm{DMSO}-\mathrm{d} 6) \delta 8.58(\mathrm{~d}, J=7.3 \mathrm{~Hz}, 1 \mathrm{H})$, $8.03(d, J=7.3 \mathrm{~Hz}, 1 \mathrm{H}), 1.35(\mathrm{~s}, 9 \mathrm{H})$.

\section{4-Trifluoromethylbenzenediazonium tetrafluoroborate (5b)}

Obtained as a white solid (462 mg, 89\%); ${ }^{1} \mathrm{H}$ NMR $(500 \mathrm{MHz}, \mathrm{DMSO}-\mathrm{d} 6) \delta 8.90(\mathrm{~d}, \mathrm{~J}=8.0 \mathrm{~Hz}, 2 \mathrm{H})$, $8.42(\mathrm{~d}, \mathrm{~J}=8.0 \mathrm{~Hz}, 2 \mathrm{H})$.

\section{2-Chlorobenzenediazonium tetrafluoroborate (5c)} Obtained as a white solid $(294 \mathrm{mg}, 65 \%) ;{ }^{1} \mathrm{H}$ NMR (500 MHz, DMSO-d6) $\delta 8.85(\mathrm{~d}, J=8.1 \mathrm{~Hz}, 1 \mathrm{H})$, $8.28(\mathrm{~d}, J=8.2 \mathrm{~Hz}, 1 \mathrm{H}), 8.20(\mathrm{~d}, J=8.4 \mathrm{~Hz}, 1 \mathrm{H})$, $7.96(t, J=6.2 \mathrm{~Hz}, 1 \mathrm{H})$.

\section{2-Trifluoromethylbenzenediazonium tetrafluoroborate (5d)}

Obtained as a white solid (369 mg, 71\%); ${ }^{1} \mathrm{H}$ NMR $(500 \mathrm{MHz}, \mathrm{DMSO}-\mathrm{d} 6) \delta 9.08(\mathrm{~d}, J=6.6 \mathrm{~Hz}, 1 \mathrm{H})$, $8.49(\mathrm{~s}, 2 \mathrm{H}), 8.39-8.30(\mathrm{~m}, 1 \mathrm{H})$.

\section{3-Fluorobenzenediazonium tetrafluoroborate (5e)} Obtained as a white solid $(231 \mathrm{mg}, 55 \%) ;{ }^{1} \mathrm{H}$ NMR (500 MHz, DMSO-d6) $\delta 8.67(\mathrm{~d}, J=6.0 \mathrm{~Hz}, 1 \mathrm{H})$, $8.59(\mathrm{~d}, J=7.8 \mathrm{~Hz}, 1 \mathrm{H}), 8.22(\mathrm{t}, J=7.4 \mathrm{~Hz}, 1 \mathrm{H})$, $8.09-8.01(\mathrm{~m}, 1 \mathrm{H})$.

4-Ethynylbenzenediazonium tetrafluoroborate (5f) Obtained as a pale brown solid (344 mg, 73\%); $1 \mathrm{H}$ NMR (500 MHz, DMSO-d6) $\delta 8.67(\mathrm{~d}, J=7.9 \mathrm{~Hz}$, $2 \mathrm{H}), 8.06(\mathrm{~d}, J=7.8 \mathrm{~Hz}, 2 \mathrm{H}), 5.15(\mathrm{~s}, 1 \mathrm{H})$.

4-Fluorobenzenediazonium tetrafluoroborate $(5 \mathrm{~g})$ Obtained as a white solid (243 mg, 58\%); $1 \mathrm{H}$ NMR $(500 \mathrm{MHz}$, DMSO-d6) $\delta 8.83-8.73(\mathrm{~m}, 2 \mathrm{H}), 7.88$ $(\mathrm{t}, \mathrm{J}=8.7 \mathrm{~Hz}, 2 \mathrm{H})$.

\section{General Procedure for Synthesis of 8- (aryldiazenyl)quinoline (6a-g)}

8 -aminoquinoline $(0.1 \mathrm{mmol}, 1.0$ equiv) and aryl diazonium salt (0.11 mmol, 1.1 equiv.) was dissolved in $2.0 \mathrm{~mL}$ distilled water and stirred 30 min at RT. Extracted with ethyl acetate, dried over $\mathrm{Na}_{2} \mathrm{SO}_{4}$ and evaporated in vacuo. The crude product was purified by silica gel column chromatography, eluting with EtOAc in hexanes to yield the desired product.

\section{(E)-5-((4-(tert-butyl)phenyl)diazenyl) quinolin-8-} amine (6a)

Obtained as a reddish-orange solid (28 $\mathrm{mg}, 92 \%)$; $\mathrm{mp}: 149-151{ }^{\circ} \mathrm{C},{ }^{1} \mathrm{H}$ NMR $\left(500 \mathrm{MHz}, \mathrm{CDCl}_{3}\right) \delta 9.31$ $(\mathrm{d}, J=8.5 \mathrm{~Hz}, 1 \mathrm{H}), 8.85(\mathrm{~s}, 1 \mathrm{H}), 8.01(\mathrm{~d}, J=7.5$ $\mathrm{Hz}, 1 \mathrm{H}), 7.91(\mathrm{~d}, J=7.5 \mathrm{~Hz}, 2 \mathrm{H}), 7.56(\mathrm{~d}, J=7.3$ $\mathrm{Hz}, 3 \mathrm{H}), 6.97(\mathrm{~d}, J=7.5 \mathrm{~Hz}, 1 \mathrm{H}), 5.50(\mathrm{~s}, 2 \mathrm{H})$, $1.41(\mathrm{~d}, \mathrm{~J}=0.9 \mathrm{~Hz}, 9 \mathrm{H}) ;{ }^{13} \mathrm{C} \mathrm{NMR}\left(126 \mathrm{MHz}, \mathrm{CDCl}_{3}\right)$ $\delta 153.28,151.39,147.82,147.79,147.42,138.43$, $137.18,132.32,127.98,125.96,125.91,122.22$, $122.18,115.10,109.02,34.92,31.31$; IR (neat, $\mathrm{cm}^{-1}$ ) 3478, 3353, 2952, 2919, 2855, 1615, 1587, $1565,1508,1473,1428,1174,1126,846,785$; 
MALDI-TOF $\quad m / z$ calcd for $\mathrm{C}_{19} \mathrm{H}_{21} \mathrm{~N}_{4}\left([\mathrm{M}+\mathrm{H}]^{+}\right)$ 305,177 , found 305.336 .

\section{(E)-5-((4-(trifluoromethyl)phenyl)diazenyl)} quinolin-8-amine (6b)

Obtained as a maroon solid (31 mg, 98\%); $\mathrm{mp}$ : 137-139 ${ }^{\circ} \mathrm{C} ;{ }^{1} \mathrm{H}$ NMR (500 MHz, $\left.\mathrm{CDCl}_{3}\right) \delta 9.28(\mathrm{~d}, \mathrm{~J}$ $=6.5 \mathrm{~Hz}, 1 \mathrm{H}), 8.85(\mathrm{~s}, 1 \mathrm{H}), 8.14-7.95(\mathrm{~m}, 3 \mathrm{H})$, $7.78(\mathrm{~d}, \mathrm{~J}=7.0 \mathrm{~Hz}, 2 \mathrm{H}), 7.58(\mathrm{~d}, \mathrm{~J}=2.2 \mathrm{~Hz}, 1 \mathrm{H})$, $7.02-6.84(\mathrm{~m}, 1 \mathrm{H}), 5.69(\mathrm{~s}, 2 \mathrm{H}) ;{ }^{13} \mathrm{C}$ NMR $(126$ $\left.\mathrm{MHz}_{1} \mathrm{CDCl}_{3}\right) \delta 155.33,148.73,147.94(\mathrm{~d}, \mathrm{~J}=3.8$ $\mathrm{Hz}), 138.02,136.89,132.14,130.79(\mathrm{q}, J=32.4$ $\mathrm{Hz}), 128.37,126.62-125.81(\mathrm{~m}), 125.22,123.05$, $122.86(\mathrm{~d}, J=5.4 \mathrm{~Hz}), 122.54,116.22,108.87$; IR (neat, $\mathrm{cm}^{-1}$ ) 3433, 3317, 2951, 2918, 2851, 1609, 1553, 1504, 1475, 1440, 1382, 1154, 1104, 1065, 843; MALDI-TOF $m / z$ calcd for $\mathrm{C}_{16} \mathrm{H}_{12} \mathrm{~F}_{3} \mathrm{~N}_{4}\left([\mathrm{M}+\mathrm{H}]^{+}\right)$ 317,101 , found 317.139 .

\section{(E)-5-((2-chlorophenyl)diazenyl)quinolin-8-amine} (6C)

Obtained as an orange solid (25 mg, 89\%); mp: 156-158 ${ }^{\circ} \mathrm{C} ;{ }^{1} \mathrm{H}$ NMR $\left(500 \mathrm{MHz} \mathrm{CDCl}_{3}\right) 9.37$ (d, $\mathrm{J}=$ $8.1 \mathrm{~Hz}, 1 \mathrm{H}), 8.85(\mathrm{~s}, 1 \mathrm{H}), 8.13(\mathrm{~d}, J=7.5 \mathrm{~Hz}, 1 \mathrm{H})$, $7.83(\mathrm{~d}, J=7.0 \mathrm{~Hz}, 1 \mathrm{H}), 7.57(\mathrm{~d}, J=4.6 \mathrm{~Hz}, 2 \mathrm{H})$, $7.35(\mathrm{t}, J=13.9 \mathrm{~Hz}, 2 \mathrm{H}), 6.98(\mathrm{~d}, J=7.0 \mathrm{~Hz}, 1 \mathrm{H})$, $5.63(\mathrm{~s}, 2 \mathrm{H}) ;{ }^{13} \mathrm{C}$ NMR $\left(126 \mathrm{MHz}, \mathrm{CDCl}_{3}\right) \delta 149.49$, $148.42,147.88,138.55,137.00,134.40,132.47$, $130.60,130.27,127.79,127.21,122.95,118.16$, 117.67, 108.96; IR (neat, $\mathrm{cm}^{-1}$ ) 3457, 3301, 2949, 2917, 2845, 1610, 1587, 1508, 1370, 1340, 1244, $1175,1120,824,785,754$; MALDI-TOF $m / z$ calcd for $\mathrm{C}_{15} \mathrm{H}_{12} \mathrm{ClN}_{4}\left([\mathrm{M}+\mathrm{H}]^{+}\right) 283,075$, found 282.933 .

\section{(E)-5-((2-(trifluoromethyl)phenyl)diazenyl)}

quinolin-8-amine (6d)

Obtained as a rust solid (30 mg, 95\%); mp: 145$147{ }^{\circ} \mathrm{C} ;{ }^{1} \mathrm{H}$ NMR $\left(500 \mathrm{MHz}, \mathrm{CDCl}_{3}\right) \delta 9.37$ (dd, $\mathrm{J}=$ $8.6,1.7 \mathrm{~Hz}, 1 \mathrm{H}), 8.85(\mathrm{dd}, J=4.1,1.7 \mathrm{~Hz}, 1 \mathrm{H})$, $8.12(\mathrm{~d}, J=8.5 \mathrm{~Hz}, 1 \mathrm{H}), 7.95(\mathrm{~d}, J=8.1 \mathrm{~Hz}, 1 \mathrm{H})$, $7.84(d, J=7.8 \mathrm{~Hz}, 1 \mathrm{H}), 7.67(t, J=7.5 \mathrm{~Hz}, 1 \mathrm{H})$, 7.59 (dd, $J=8.6,4.1 \mathrm{~Hz}, 1 \mathrm{H}), 7.50(\mathrm{t}, J=7.6 \mathrm{~Hz}$, $1 \mathrm{H}), 6.98(\mathrm{~d}, J=8.5 \mathrm{~Hz}, 1 \mathrm{H}), 5.72(\mathrm{~s}, 2 \mathrm{H}) ;{ }^{13} \mathrm{C} \mathrm{NMR}$ $\left(126 \mathrm{MHz}, \mathrm{CDCl}_{3}\right) \delta 175.95,150.49,148.69$, $147.87,138.42,136.85,132.40(d, J=4.5 \mathrm{~Hz})$, $128.90,128.06,126.71-126.25(\mathrm{~m}), 125.40$, $122.96,118.26,116.35,109.12$; IR (neat, $\mathrm{cm}^{-1}$ ) $3458,3318,2952,2915,2851,1621,1600,1506$, $1424,1387,1310,1238,1130,1048,1032,815$, 791,751 ; MALDI-TOF $\mathrm{m} / \mathrm{z}$ calcd for $\mathrm{C}_{16} \mathrm{H}_{12} \mathrm{~F}_{3} \mathrm{~N}_{4}$ ([M $\left.+\mathrm{H}^{+}\right)$317,101, found 317.072 .

\section{(E)-5-((3-fluorophenyl)diazenyl)quinolin-8-amine} (6e)

Obtained as a rust solid (24 mg, 91\%); mp: 136$138{ }^{\circ} \mathrm{C} ;{ }^{1} \mathrm{H}$ NMR $\left(500 \mathrm{MHz}, \mathrm{CDCl}_{3}\right) \delta 9.19$ (dd, $\mathrm{J}=$ $8.5,1.7 \mathrm{~Hz}, 1 \mathrm{H}), 8.75$ (dd, $J=4.1,1.7 \mathrm{~Hz}, 1 \mathrm{H}$ ), $7.95(\mathrm{~d}, J=8.5 \mathrm{~Hz}, 1 \mathrm{H}), 7.69(\mathrm{dd}, J=7.9,0.6 \mathrm{~Hz}$, $1 \mathrm{H}), 7.62-7.52(\mathrm{~m}, 1 \mathrm{H}), 7.48(\mathrm{dd}, J=8.5,4.1 \mathrm{~Hz}$, $1 \mathrm{H}), 7.40(\mathrm{td}, \mathrm{J}=8.0,6.1 \mathrm{~Hz}, 1 \mathrm{H}), 7.08-6.99(\mathrm{~m}$, $1 \mathrm{H}), 6.89-6.83(\mathrm{~m}, 1 \mathrm{H}), 5.52(\mathrm{~s}, 2 \mathrm{H}) ;{ }^{13} \mathrm{C} N M R$ $\left(126 \mathrm{MHz} \mathrm{CDCl}_{3}\right) \delta 164.41,162.45,155.06(\mathrm{~d}, \mathrm{~J}=$
$7.1 \mathrm{~Hz}), 148.35,147.95,137.91,137.02,132.22$, $130.15(\mathrm{~d}, J=8.5 \mathrm{~Hz}), 128.28,122.75,120.23$ (d, $J=2.7 \mathrm{~Hz}), 116.47,116.30,115.87,108.94$, 107.56, 107.38; IR (neat, $\mathrm{cm}^{-1}$ ) 3430, 3309, 3165, 2951, 2920, 2851, 1729, 1619, 1566, 1508, 1475, $1379,1335,1246,1205,1100,965,866,780,682$; MALDI-TOF $m / z$ calcd for $\mathrm{C}_{15} \mathrm{H}_{12} \mathrm{FN}_{4}\left([\mathrm{M}+\mathrm{H}]^{+}\right)$ 267,1046 , found 266.992 .

\section{(E)-5-((4-ethynylphenyl)diazenyl)quinolin-8-amine (6f)}

Obtained as a rust solid (23 mg, 84\%); mp: 186$188{ }^{\circ} \mathrm{C} ;{ }^{1} \mathrm{H}$ NMR $\left(500 \mathrm{MHz}, \mathrm{CDCl}_{3}\right) \delta 9.30(\mathrm{~d}, \mathrm{~J}=$ $8.2 \mathrm{~Hz}, 1 \mathrm{H}), 8.85(\mathrm{~s}, 1 \mathrm{H}), 8.05(\mathrm{~d}, \mathrm{~J}=8.3 \mathrm{~Hz}, 1 \mathrm{H})$, $7.92(\mathrm{~d}, J=8.2 \mathrm{~Hz}, 2 \mathrm{H}), 7.71-7.51(\mathrm{~m}, 3 \mathrm{H}), 6.97$ $(\mathrm{d}, J=8.2 \mathrm{~Hz}, 1 \mathrm{H}), 5.60(\mathrm{~s}, 2 \mathrm{H}), 3.23(\mathrm{~s}, 1 \mathrm{H}) ;{ }^{13} \mathrm{C}$ NMR $\left(126 \mathrm{MHz}_{2} \mathrm{CDCl}_{3}\right) \delta 153.09,148.23,147.88$, $138.23,137.02,132.96,132.22,128.23,123.17$, $122.65,122.41,115.73,108.96,83.62,78.92$; IR (neat, $\mathrm{cm}^{-1}$ ) 3429, 3305, 3177, 2923, 2847, 1719, 1611 , 1508, 1378, 1328, 1246, 1192, 839, 790; MALDI-TOF $m / z$ calcd for $\mathrm{C}_{17} \mathrm{H}_{13} \mathrm{~N}_{4}\left([\mathrm{M}+\mathrm{H}]^{+}\right)$ 273,114 , found 272.861 .

\section{(E)-5-((4-fluorophenyl)diazenyl)quinolin-8-amine (6g)}

Obtained as an orange solid (26 mg, 96\%); $\mathrm{mp}$ : $162-164{ }^{\circ} \mathrm{C} ;{ }^{1} \mathrm{H}$ NMR $\left(500 \mathrm{MHz} \mathrm{CDCl}_{3}\right) \delta 9.28(\mathrm{~d}, J$ $=6.7 \mathrm{~Hz}, 1 \mathrm{H}), 8.85(\mathrm{~s}, 1 \mathrm{H}), 8.00(\mathrm{~d}, \mathrm{~J}=21.5 \mathrm{~Hz}$, $3 \mathrm{H}), 7.57(\mathrm{~d}, J=4.3 \mathrm{~Hz}, 1 \mathrm{H}), 7.22(\mathrm{~s}, 2 \mathrm{H}), 7.03-$ $6.92(\mathrm{~m}, 1 \mathrm{H}), 5.55(\mathrm{~s}, 2 \mathrm{H}) ;{ }^{13} \mathrm{C} \mathrm{NMR}(126 \mathrm{MHz}$, $\mathrm{CDCl} 3) \delta 164.61,162.61,149.98,147.86(\mathrm{~d}, \mathrm{~J}=$ $5.0 \mathrm{~Hz}), 147.78,138.04,137.09,132.18,128.03$, $125.03-123.91(\mathrm{~m}), 122.50(\mathrm{dd}, J=7.9,5.7 \mathrm{~Hz})$, $115.91(\mathrm{dd}, \mathrm{J}=23.3,6.2 \mathrm{~Hz}), 115.38(\mathrm{~d}, \mathrm{~J}=5.0$ $\mathrm{Hz}), 108.95$; IR (neat, $\mathrm{cm}^{-1}$ ) 3446, 3321, 2925, 2851, 1615, 1591, 1567, 1510, 1492, 1385, 1334, $1248,1223,1184,847,788$; MALDI-TOF $\mathrm{m} / \mathrm{z}$ calcd for $\mathrm{C}_{15} \mathrm{H}_{12} \mathrm{FN}_{4}\left([\mathrm{M}+\mathrm{H}]^{+}\right) 267,105$, found 266.961 .

\section{RESULTS AND DISCUSSION}

In this work, novel azobenzenes (6a-g) have been synthesized with excellent yields. The synthetic route has been illustrated in Scheme 1. At first, quinoline was nitrated in the presence of nitric acid and sulfuric acid, and a mixture of 5-nitroqoinoline and 8-nitroquinoline (2a-b) was obtained. Without any purification, this mixture was subjected for hydrogenolysis in the presence of $\mathrm{H}_{2} / \mathrm{Pd}$ and amino quinoline forms (3a-b) were attained by full conversion. On the other hand, aniline derivatives were converted to the corresponding diazonium salts (5a-g) in single step with good and acceptable yields. Finally, azobenzenes as target products were synthesized by reacting with 8 -aminoquinoline (3a) and aryl diazonium salts (5a-g) in aqueous media at room temperature in facile manner. Diazonium salts with electron donating or withdrawing groups substituted at different positions of benzene gave the target product 8-(aryldiazenyl)quinolines (6a-g) quite successfully with exceptional yields. Structural 
features of the 8-(aryldiazenyl)quinolines (6a-g) were fully elucidated using NMR, UV-Visible absorption spectra and mass spectrometry.<smiles>O=[N+]([O-])c1cccc2ncccc12</smiles><smiles></smiles>

1

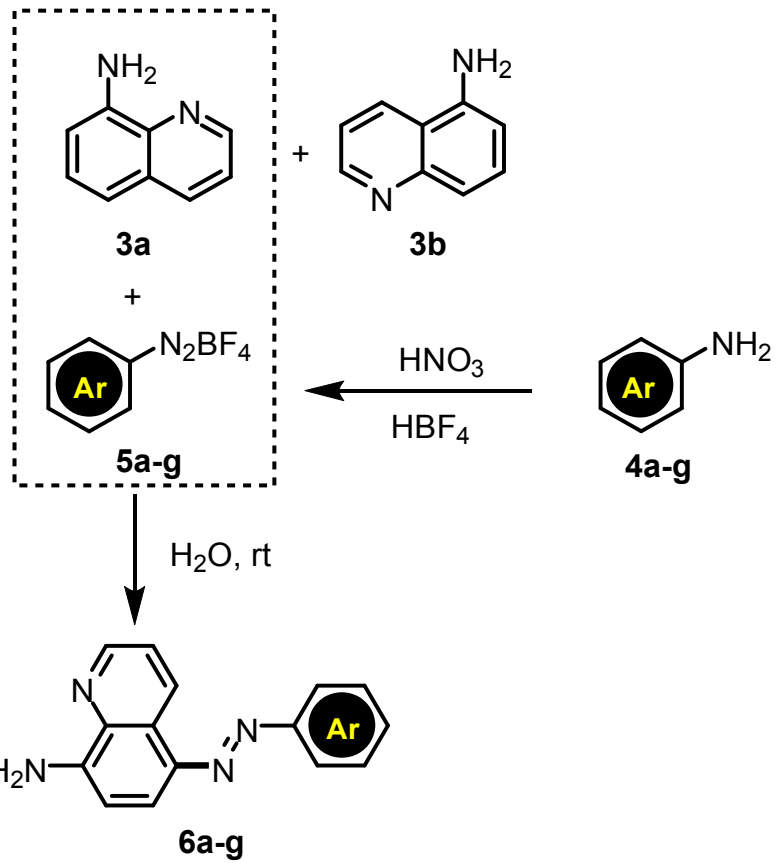<smiles>CC(C)(C)c1ccc(N=Nc2ccc(N)c3ncccc23)cc1</smiles>

$6 a, 92 \%$<smiles>Nc1ccc(N=Nc2ccc(C(F)(F)F)cc2)c2cccnc12</smiles>

$6 b, 98 \%$<smiles>Nc1ccc(N=Nc2ccccc2Cl)c2cccnc12</smiles>

$6 c, 89 \%$<smiles>Nc1ccc(N=Nc2ccccc2C(F)(F)F)c2cccnc12</smiles>

$6 d, 95 \%$<smiles>Nc1ccc(N=Nc2cccc(F)c2)c2cccnc12</smiles>

$6 e, 91 \%$<smiles>C#Cc1ccc(/N=N/c2ccc(N)c3ncccc23)cc1</smiles>

$6 f, 84 \%$<smiles>Nc1ccc(N=Nc2ccc(F)cc2)c2cccnc12</smiles>

$6 \mathrm{~g}, 96 \%$

Figure 1: Synthetic route for the preparation of azobenzenes.

UV-Vis spectra of the compounds were collected in acetonitrile solvent with Shimadzu UV-3600 UV-Vis NIR spectrophotometer and they were presented in Figure 2. Their maximal values and molar absorption coefficients were also recorded in Table 1. As seen in Table 1 , the absorption maximal values of the compounds are between $427 \mathrm{~nm}$ and $445 \mathrm{~nm}$ due to $\Pi-\Pi^{*}$ charge transfer transition (52).
The absorption bands are slightly shifted to longer wavelengths (redshifted) in the order of $\mathbf{6 a}, \mathbf{6 g}, \mathbf{6 c}$, 6e, 6b, 6d, and $\mathbf{6 f}$. Generally, as the electron donor strength increases, the absorption band maximum shifts to longer wavelengths (53); however, here the opposite effects were observed, similar to the literature (54). When their molar absorption coefficient was compared, $6 \mathbf{a}$ had the 
biggest molar absorption coefficient and $\mathbf{6 f}$ had the lowest molar absorption coefficient among the compounds presented. It can be concluded that the compounds have more absorbance ability in the strong donor systems.

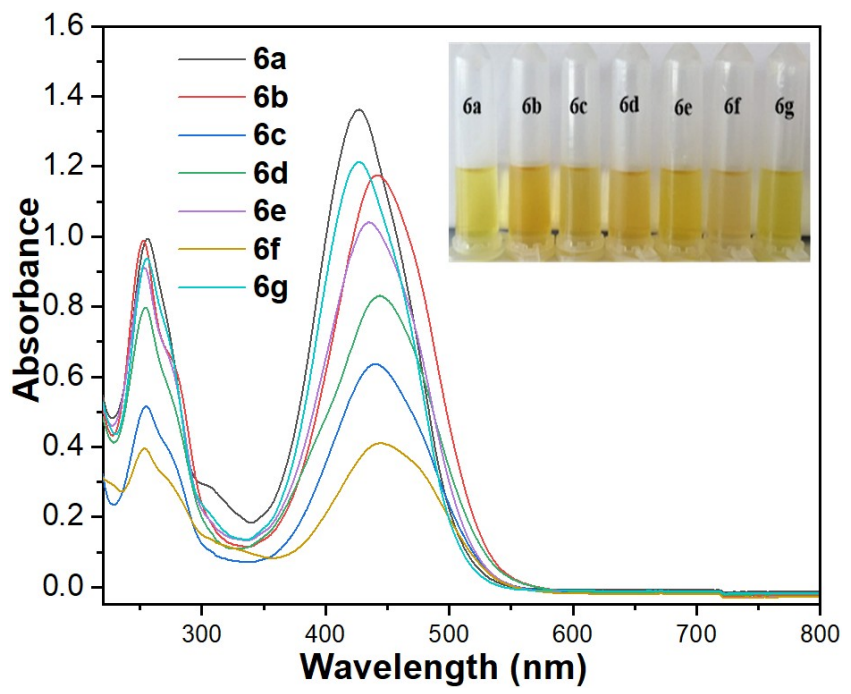

Figure 2: UV-Vis spectrum of the compounds $(50 \mu \mathrm{M})$ in $A C N$.

Table 1: Absorption maximal values of the compounds.

\begin{tabular}{ccc}
\hline Compounds & Absorption Maxima & $\begin{array}{c}\text { Molar Absorption } \\
\text { Coefficient }(\boldsymbol{\varepsilon})\left(\mathbf{c m}^{\mathbf{- 1}} \mathbf{M}^{\mathbf{- 1}}\right)\end{array}$ \\
\hline $\mathbf{6 a}$ & 427 & 27,180 \\
$\mathbf{6 b}$ & 442 & 23,500 \\
$\mathbf{6 c}$ & 430 & 12,640 \\
$\mathbf{6 d}$ & 442 & 16,560 \\
$\mathbf{6 e}$ & 435 & 20,740 \\
$\mathbf{6 f}$ & 445 & 8,260 \\
$\mathbf{6 g}$ & 428 & 24,220 \\
\hline
\end{tabular}

\section{CONCLUSION}

As a summary, the author hereby discloses the simple, easy and operational synthesis of novel 8(aryldiazenyl)quinolones and their structural characterization was carried out by varied analytical techniques as NMR, IR, UV-Visible, and mass spectroscopy. The compounds were provided with excellent yields ranging from $89 \%$ to $98 \%$. UV-Vis spectrum of the azobenzenes was collected in acetonitrile solvent and maximal values were measured between $427 \mathrm{~nm}$ and $445 \mathrm{~nm}$. The molar absorptivity of compounds showed that their electronic transition is by virtue of $\Pi-\Pi^{*}$. It can be assumed that the compounds have greater absorbance ability in strong donor systems. New azobenzenes with potentially dye and pharmaceutical agents due to the aminoquinoline backbone and diazo unit were brought to the literature.

\section{CONFLICT OF INTEREST}

There are no conflicts to declare.

\section{REFERENCES}

1. Bafana A, Devi SS, Chakrabarti T. Azo dyes: past, present and the future. Environmental Reviews. 2011;19:350-71. <DOI>

2. Hunger $\mathrm{K}$, Schmidt MU. Industrial Organic Pigments [Internet]. Wiley; 2018. <DOI >.

3. Banghart MR, Mourot A, Fortin D, Yao JZ, Kramer $\mathrm{RH}$, Trauner D. Photochromic Blockers of Voltage-Gated Potassium Channels. Angewandte Chemie International Edition. 2009;48(48):9097-101. <DOI $>$.

4. Lim SY, Hong $\mathrm{KH}$, Kim D Il, Kwon $\mathrm{H}$, Kim $\mathrm{HJ}$. Tunable Heptamethine-Azo Dye Conjugate as an NIR Fluorescent Probe for the Selective Detection of Mitochondrial Glutathione over Cysteine and Homocysteine. Journal of the American Chemical Society. 2014;136(19): 7018-25. <DOI>.

5. DiCesare N, Lakowicz JR. New Color Chemosensors for Monosaccharides Based on Azo Dyes. Organic Letters. 2001;3(24):3891-3. <DOI>.

6. Chang KC, Su IH, Wang YY, Chung WS. A Bifunctional Chromogenic Calix[4]arene Chemosensor for Both Cations and Anions: A Potential $\mathrm{Ca}^{2+}$ and $\mathrm{F}^{-}$Switched 
Inhıbıt Logic Gate with a YES Logic Function. European Journal of Organic Chemistry. 2010;2010(24):4700-4. $<$ DOI $>$.

7. Leulescu M, Rotaru A, Moanţă A, Iacobescu G, Pălărie I, Cioateră N, et. al. Azorubine: physical, thermal and bioactive properties of the widely employed food, pharmaceutical and cosmetic red azo dye material. Journal of Thermal Analysis and Calorimetry. 2021;143(6):394567. $\leq$ DOI $>$.

8. Wang LH, Shu-Juan $H$. Studies on the voltammetric behavior of azo dyes and its determination in cosmetic products1. Russian Journal of Electrochemistry. 2010;46(12):1414-8. <DOI $>$.

9. Rawat D, Sharma RS, Karmakar S, Arora LS, Mishra V. Ecotoxic potential of a presumably non-toxic azo dye. Ecotoxicology and Environmental Safety. 2018;148:528-37. <DOI $>$.

10. Khaligh NG, Hamid SBA, Hazarkhani H. TiO 2 nanotubes and sonication: Synthesis of azo-linked xanthenes. Inorganic and Nano-Metal Chemistry. 2017;47(10):1468-74. <DOI .

11. Merino E. Synthesis of azobenzenes: the coloured pieces of molecular materials. Chemical Society Reviews. 2011;40(7):3835-53. <DOI $>$.

12. Qıu F, Cao Y, Xu H, Jiang Y, Zhou Y, Liu J. Synthesis and properties of polymer containing azo-dye chromophores for nonlinear optical applications. Dyes and Pigments. 2007;75(2):454-9. <DOI $>$.

13. Çanakçı D, Serin S. Synthesis of new azo dye polymers based on naphthol by oxidative polycondensation: antimicrobial activity and fastness studies. Journal of Polymer Research. 2020;27(1):11. <DOI $>$.

14. Çanakçı D. Synthesis, Spectroscopic, Thermodynamics and Kinetics Analysis Study of Novel Polymers Containing Various Azo Chromophore. Scientific Reports. 2020;10(1):477. <DOI $>$.

15. Farghaly TA, Abdallah ZA. Synthesis, azohydrazone tautomerism and antitumor screening of $\mathrm{N}$-(3ethoxycarbonyl-4,5,6,7-tetrahydro-benzo[b]thien-2-yl)-2arylhydrazono-3-oxo butanamide derivatives. Arkivoc. 2009;2008(17):295-305. <DOI>.

16. Ali $Y$, Hamid SA, Rashid U. Biomedical Applications of Aromatic Azo Compounds. Mini-Reviews in Medicinal Chemistry. 2018;18(18):1548-58. <DOI>

17. Akram D, Elhaty IA, AINeyadi SS. Synthesis and Antibacterial Activity of Rhodanine-Based Azo Dyes and Their Use as Spectrophotometric Chemosensor for $\mathrm{Fe}^{3+}$ Ions. Chemosensors. 2020;8(1):16. <DOI>.

18. Unnisa A, Abouzied AS, Baratam A, Chenchu Lakshmi KNV, Hussain T, Kunduru RD, et. al. Design, synthesis, characterization, computational study and invitro antioxidant and anti-inflammatory activities of few novel 6-aryl substituted pyrimidine azo dyes. Arabian Journal of Chemistry. 2020;13(12):8638-49. <DOI>

19. Kennedy DA, Vembu N, Fronczek FR, Devocelle M. Synthesis of Mutual Azo Prodrugs of Anti-inflammatory Agents and Peptides Facilitated by a-Aminoisobutyric Acid. The Journal of Organic Chemistry. 2011;76(23):9641-7. $<\mathrm{DOI}>$.

20. Adu JK, Amengor CDK, Mohammed Ibrahim N, Amaning-Danquah C, Owusu Ansah C, Gbadago DD, vd. Synthesis and In Vitro Antimicrobial and Anthelminthic Evaluation of Naphtholic and Phenolic Azo Dyes. Journal of Tropical Medicine. 2020;2020:1-8. <DOI>.

21. Shaki H, Gharanjig K, Khosravi A. Synthesis and investigation of antimicrobial activity and spectrophotometric and dyeing properties of some novel azo disperse dyes based on naphthalimides. Biotechnology Progress. 2015;31(4):1086-95. <DOI $>$.

22. Saeed AM, AlNeyadi SS, Abdou IM. Anticancer activity of novel Schiff bases and azo dyes derived from 3amino-4-hydroxy-2H-pyrano[3,2-c]quinoline-2,5(6H)dione. Heterocyclic Communications. 2020;26(1):192205. $<$ DOI $>$.

23. Abd-El-Aziz AS, Alsaggaf A, Assirey E, Naqvi A, Okasha RM, Afifi $T H$, et. al. A New Family of Benzo[h]Chromene Based Azo Dye: Synthesis, In-Silico and DFT Studies with In Vitro Antimicrobial and Antiproliferative Assessment. International Journal of Molecular Sciences. 2021;22(6):2807. <DOI>.

24. Tahir T, Shahzad MI, Tabassum R, Rafiq $M$, Ashfaq $M$, Hassan $M$, et. al. Diaryl azo derivatives as antidiabetic and antimicrobial agents: synthesis, in vitro, kinetic and docking studies. Journal of Enzyme Inhibition and Medicinal Chemistry. 2021;36(1):1509-20. <DOI>.

25. Mallikarjuna NM, Keshavayya J. Synthesis, spectroscopic characterization and pharmacological studies on novel sulfamethaxazole based azo dyes. Journal of King Saud University - Science. 2020;32(1):251-9. <DOI .

26. Dusan M, Biljana BN, Bozıc B, Kovrlıja I, Ladarevıc J, Uscumlıc G. Synthesis, solvatochromism, and biological activity of novel azo dyes bearing 2-pyridone and benzimidazole moieties. Turkish Journal Of Chemistry. $2018 ; 42(3)$. <DOI $>$.

27. Surucu O, Abaci S, Seferoğlu Z. Electrochemical characterization of azo dye (E)-1-(4-((4(phenylamino)phenyl)diazenyl)phenyl)ethanone (DPA). Electrochimica Acta. 2016;195:175-83. <DOI $>$.

28. Harisha S, Keshavayya J, Kumara Swamy BE, Viswanath CC. Synthesis, characterization and electrochemical studies of azo dyes derived from barbituric acid. Dyes and Pigments. 2017;136:742-53. <DOI>.

29. Grand View Research. Dyes \& Pigments Market Size, Share \& Trends Analysis Report [Internet]. 2021.

30. Carliell CM, Barclay SJ, Shaw C, Wheatley AD, 
Buckley CA. The Effect of Salts Used in Textile Dyeing on Microbial Decolourisation of a Reactive Azo Dye. Environmental Technology. 1998;19(11):1133-7. <DOI>.

31. He Y, Zhao N, Qiu L, Zhang X, Fan X. Regio- and Chemoselective Mono- and Bisnitration of 8-Amino quinoline Amides with $\mathrm{Fe}(\mathrm{NO} 3) 3 \cdot 9 \mathrm{H} 2 \mathrm{O}$ as Promoter and Nitro Source. Organic Letters. 2016;18(23):6054-7. $\leq$ DOI $>$.

32. Nanayakkara NPD, Ager AL, Bartlett MS, Yardley V, Croft SL, Khan IA, et. al. Antiparasitic Activities and Toxicities of Individual Enantiomers of the 8Aminoquinoline 8-[(4-Amino-1-Methylbutyl)Amino $]-6-$ Methoxy-4-Methyl-5-[3,4-Dichlorophenoxy]Quinoline Succinate. Antimicrobial Agents and Chemotherapy. 2008;52(6):2130-7. <DOI $>$.

33. Warhurst DC. Understanding resistance to antimalarial 4-aminoquinolines, cinchona alkaloids and the highly hydrophobic arylaminoalcohols. Current Science. 2007;92:1556-60.

34. Bray P, Park B, Asadollaly E, Biagini G, Jeyadevan J, Berry $\mathrm{N}$, et. al. A Medicinal Chemistry Perspective on 4Aminoquinoline Antimalarial Drugs. Current Topics in Medicinal Chemistry. 2006;6(5):479-507. <DOI >.

35. Golden EB, Cho H-Y, Hofman FM, Louie SG, Schönthal $\mathrm{AH}$, Chen TC. Quinoline-based antimalarial drugs: a novel class of autophagy inhibitors. Neurosurgical Focus. 2015;38(3):E12. <DOI $>$.

36. Vandekerckhove S, D'hooghe M. Quinoline-based antimalarial hybrid compounds. Bioorganic \& Medicinal Chemistry. 2015;23(16):5098-119. <DOI>

37. Foley $M$, Tilley L. Quinoline antimalarials: Mechanisms of action and resistance. International Journal for Parasitology. 1997;27(2):231-40. <DOI>.

38. Egan TJ, Ncokazi KK. Quinoline antimalarials decrease the rate of $\beta$-hematin formation. Journal of Inorganic Biochemistry. 2005;99(7):1532-9. <DOI .

39. Kaur K, Jain M, Reddy RP, Jain R. Quinolines and structurally related heterocycles as antimalarials. European Journal of Medicinal Chemistry. 2010;45(8):3245-64. $<$ DOI $>$.

40. Oliphant CM, Green GM. Quinolones: a comprehensive review. American Family Physician. $2002 ; 65(3): 455-64$.

41. Romero AH. Role of Trifluoromethyl Substitution in Design of Antimalarial Quinolones: a Comprehensive Review. Topics in Current Chemistry. 2019;377(2):9. $\leq$ DOI $>$.

42. King $\mathrm{DE}$, Malone R, Lilley $\mathrm{SH}$. New classification and update on the quinolone antibiotics. American Family Physician. 2000;61(9):2741-8.

43. Prachayasittikul $V$, Prachayasittikul $V_{1}$ Prachayasittikul S, Ruchirawat S. 8-Hydroxyquinolines: a review of their metal chelating properties and medicinal applications. Drug Design, Development and Therapy. 2013;1157. <DOI>.

44. Zhu C, Wang Y, Mao Q, Li F, Li Y, Chen C. Two 8Hydroxyquinolinate Based Supramolecular Coordination Compounds: Synthesis, Structures and Spectral Properties. Materials. 2017;10(3):313. <DOI $>$.

45. Kuchárová $V$, Kuchár J, Zaric $M$, Canovic $P$, Arsenijevic $\mathrm{N}$, Volarevic $\mathrm{V}$, et. al. Low-dimensional compounds containing bioactive ligands. Part $\mathrm{XI}$ : Synthesis, structures, spectra, in vitro anti-tumor and antimicrobial activities of $3 \mathrm{~d}$ metal complexes with 8hydroxyquinoline-5-sulfonic acid. Inorganica Chimica Acta. 2019;497:119062. <DOI>.

46. DiMauro EF, Mamai A, Kozlowski MC. Synthesis, Characterization, and Metal Complexes of a Salen Ligand Containing a Quinoline Base. Organometallics. 2003;22(4):850-5. <DOI >.

47. Allu S, Swamy KCK. Ruthenium-catalyzed synthesis of isoquinolones with 8-aminoquinoline as a bidentate directing group in $\mathrm{C}-\mathrm{H}$ functionalization. The Journal of organic chemistry. 2014;79 9:3963-72.

48. Reddy BVS, Reddy LR, Corey EJ. Novel acetoxylation and $\mathrm{C}-\mathrm{C}$ coupling reactions at unactivated positions in alpha-amino acid derivatives. Organic Letters. 2006;8(15):3391-4. <DOI>

49. Pedron J, Boudot $C$, Hutter $S$, Bourgeade-Delmas $S$, Stigliani JL, Sournia-Saquet $A$, et. al. Novel 8nitroquinolin-2 $(1 \mathrm{H})$-ones as NTR-bioactivated antikinetoplastid molecules: Synthesis, electrochemical and SAR study. European Journal Of Medicinal Chemistry. 2018;155:135-52.

50. Ferlin MG, Chiarelotto G, Castagliuolo I. Synthesis and characterization of some $\mathrm{N}$-mannich bases of $[1,2,3]$ triazoloquinolines. Journal of Heterocyclic Chemistry. 2002;39(4):631-8. <DOI>.

51. Hari DP, Schroll P, König B. Metal-free, visiblelight-mediated direct $\mathrm{C}-\mathrm{H}$ arylation of heteroarenes with aryl diazonium salts. Journal of the American Chemical Society. 2012;134 6:2958-61.

52. Ouyang $X$, Zeng $H$, Xie $Y$. Synthesis and photoluminescence properties of 8-hydroxyquinoline derivatives and their metallic complexes. Frontiers of Chemistry in China. 2007;2(4):407-13. <DOI $>$.

53. Elangovan A, Yang SW, Lin JH, Kao KM, Ho TI. Synthesis and electrogenerated chemiluminescence of donor-substituted phenylquinolinylethynes and phenylisoquinolinylethynes: effect of positional isomerism. Organic \& Biomolecular Chemistry. 2004;2(11):1597. $\leq \mathrm{DOI}>$. 
54. Slodek A, Filapek M, Szafraniec G, Grudzka I, Pisarski WA, Malecki JG, et. al. Synthesis,
Electrochemistry, Crystal Structures, and Optical Motif. European Journal of Organic Chemistry. 2014;2014(24):5256-64. <DOI>.

Properties of Quinoline Derivatives with a 2,2'-Bithiophene 
${ }^{1} \mathrm{H} \mathrm{NMR}\left(\mathrm{CDCl}_{3}, 500 \mathrm{MHz}\right)$ spectrum of 4-tert-butylbenzenediazonium tetrafluoroborate (5a)

$$
\overbrace{\substack{n \rightarrow 0 \\ \infty}}^{\infty} \overbrace{\substack{0 \\ \infty}}^{\infty}
$$
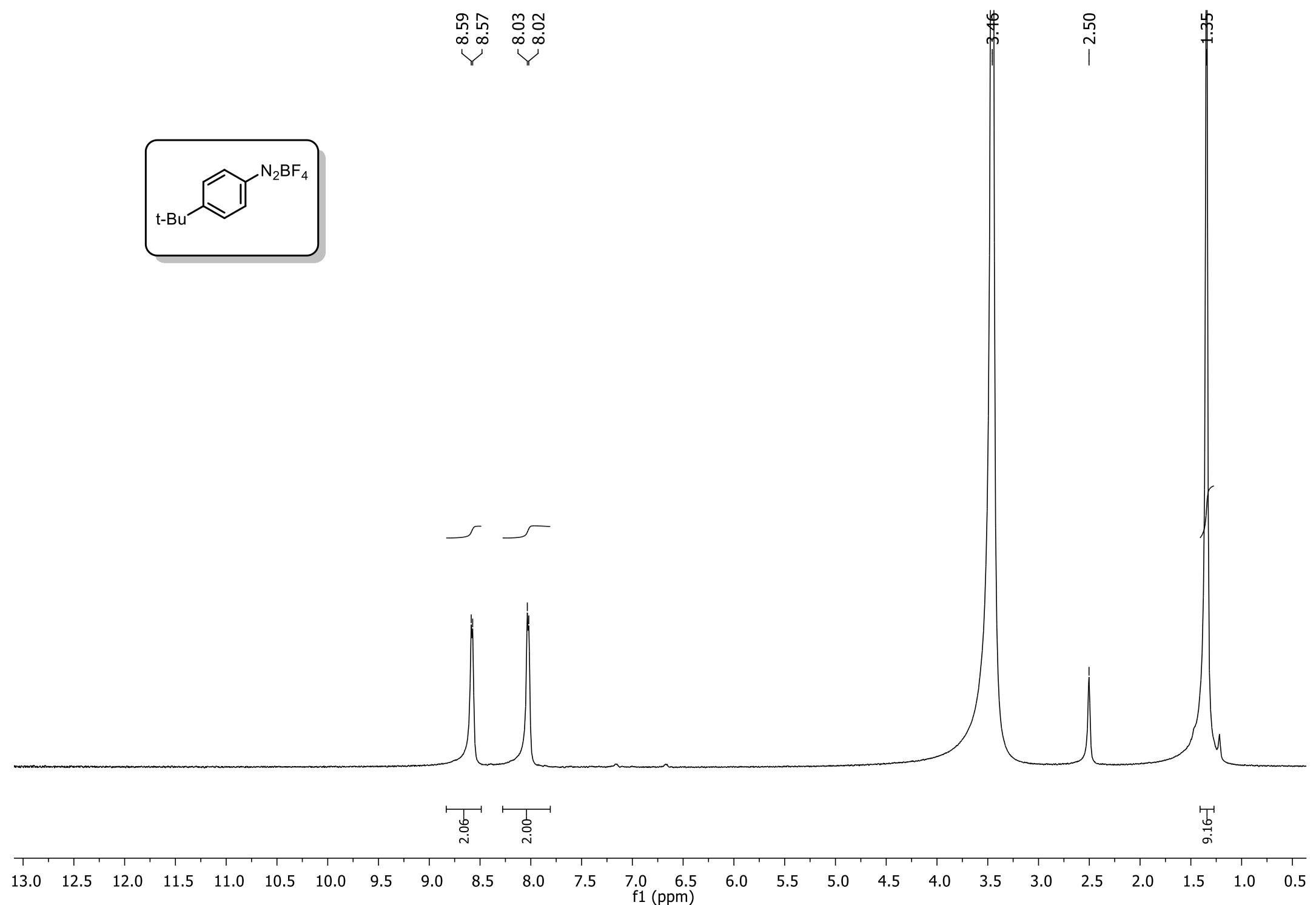
${ }^{1} \mathrm{H} \mathrm{NMR}\left(\mathrm{CDCl}_{3}, 500 \mathrm{MHz}\right)$ spectrum of 4-trifluoromethylbenzenediazonium tetrafluoroborate (5b)

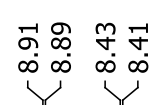

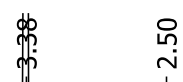
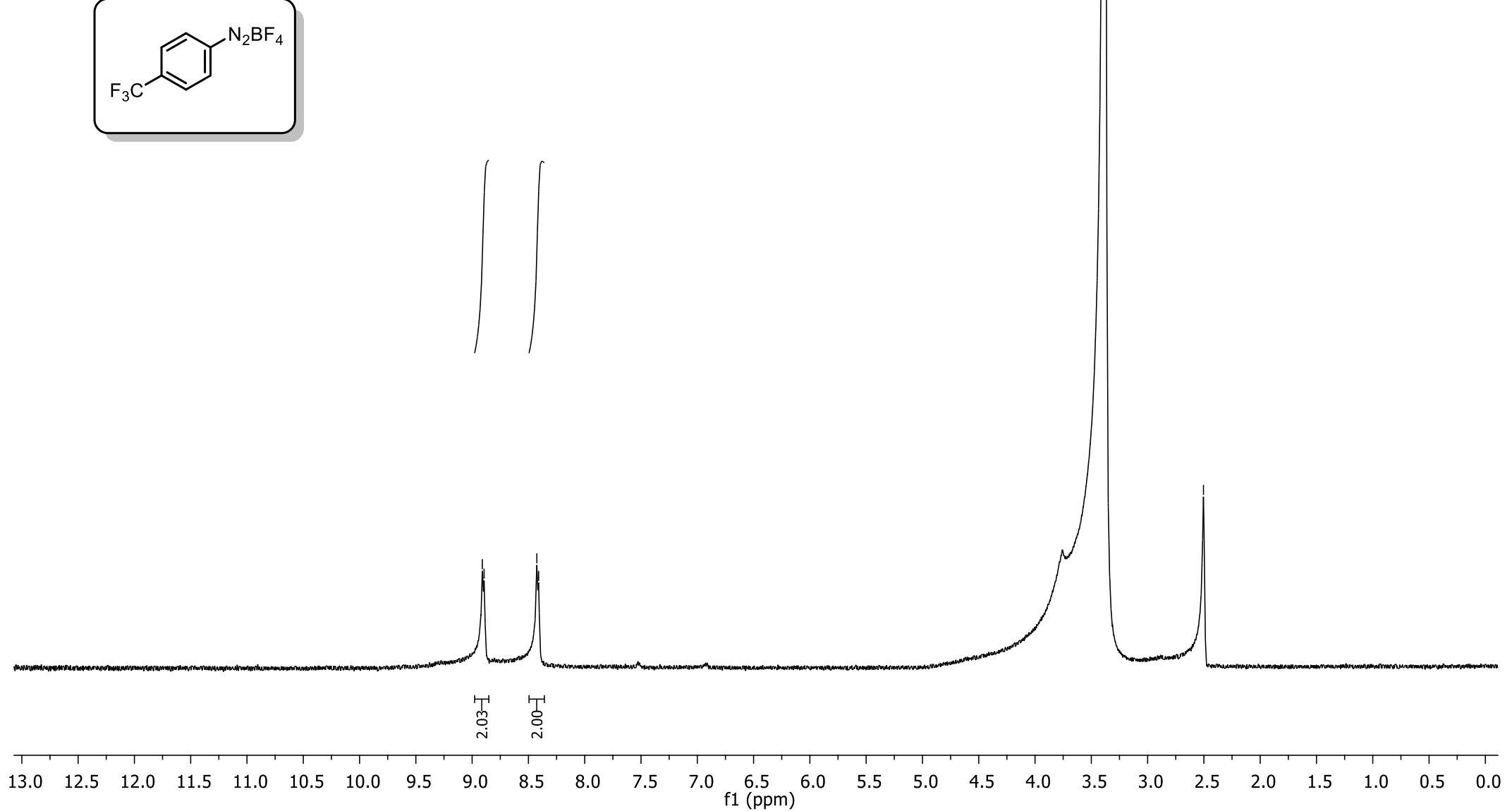
${ }^{1} \mathrm{H} \mathrm{NMR}\left(\mathrm{CDCl}_{3}, 500 \mathrm{MHz}\right)$ spectrum of 2-chlorobenzenediazonium tetrafluoroborate (5c)

$$
\text { 丩丶 }
$$
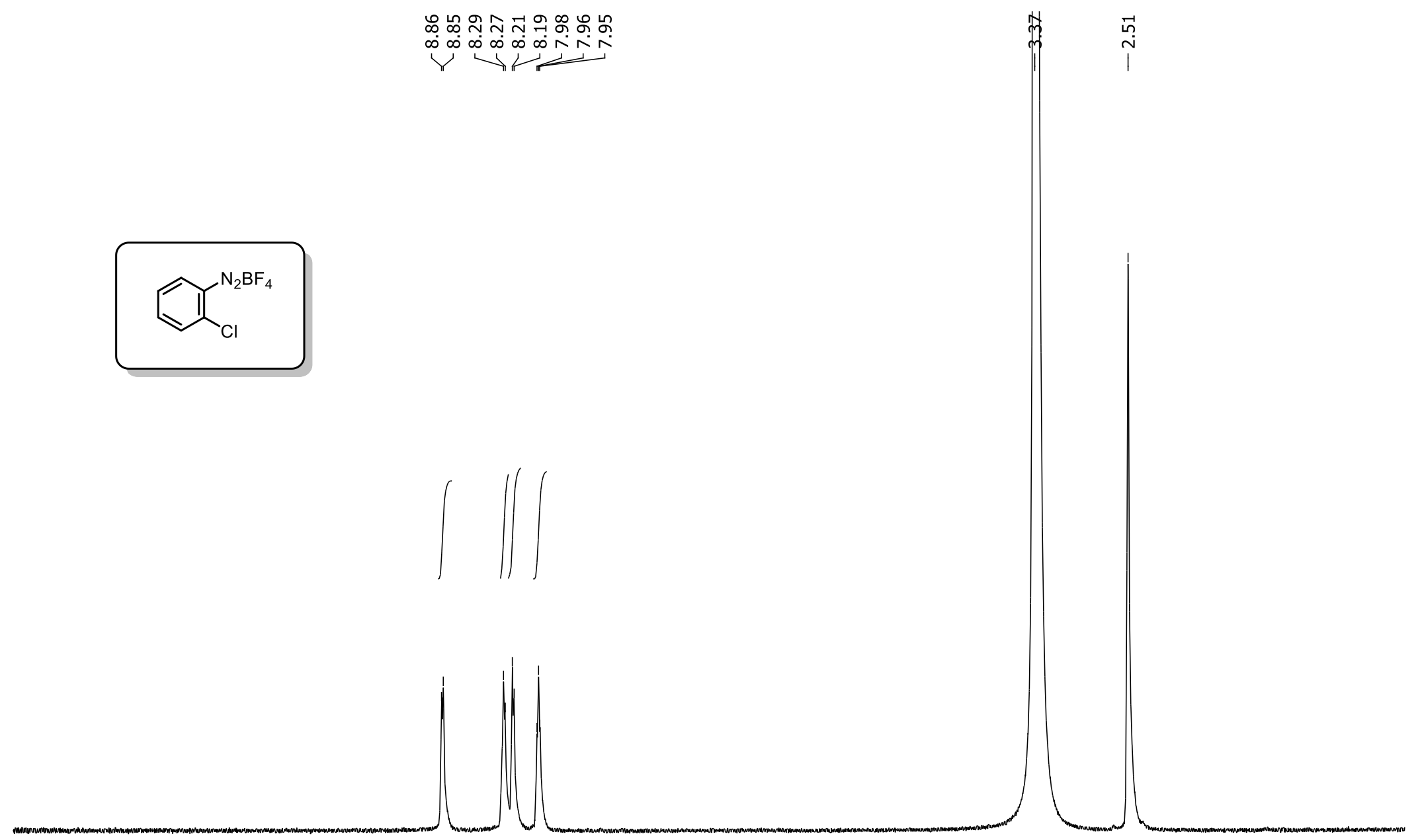

崇管雪 8.5 $8.0 \quad 7.5$ $7.0 \quad 6.5$
$\mathrm{f} 1(\mathrm{ppm})$ 
${ }^{1} \mathrm{H} \mathrm{NMR}\left(\mathrm{CDCl}_{3}, 500 \mathrm{MHz}\right)$ spectrum of 2-trifluoromethylbenzenediazonium tetrafluoroborate (5d)

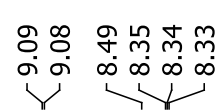
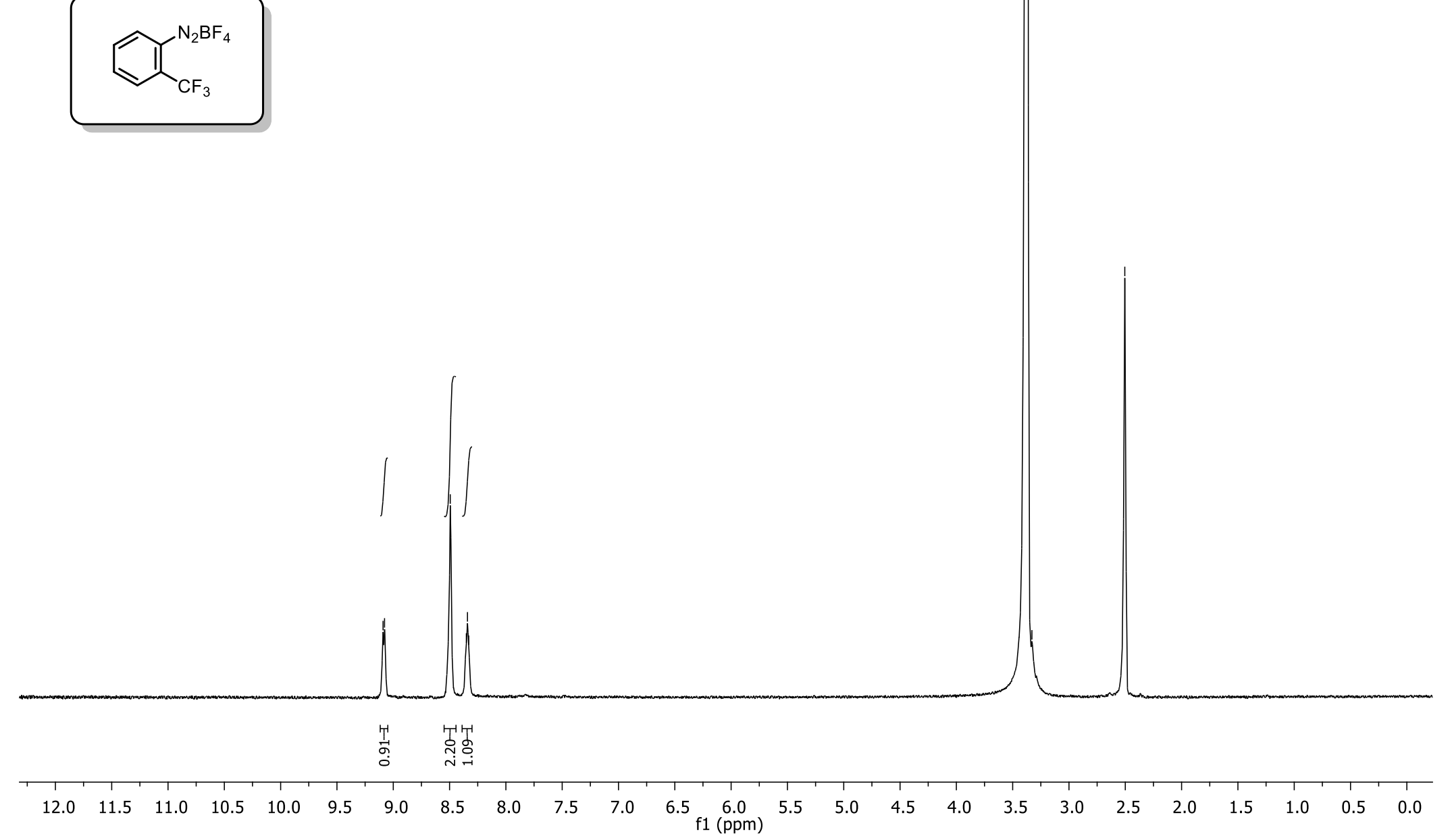
${ }^{1} \mathrm{H} \mathrm{NMR}\left(\mathrm{CDCl}_{3}, 500 \mathrm{MHz}\right)$ spectrum of 3-fluorobenzenediazonium tetrafluoroborate (5e)

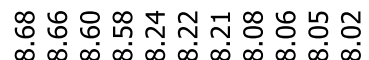

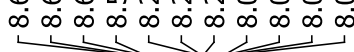
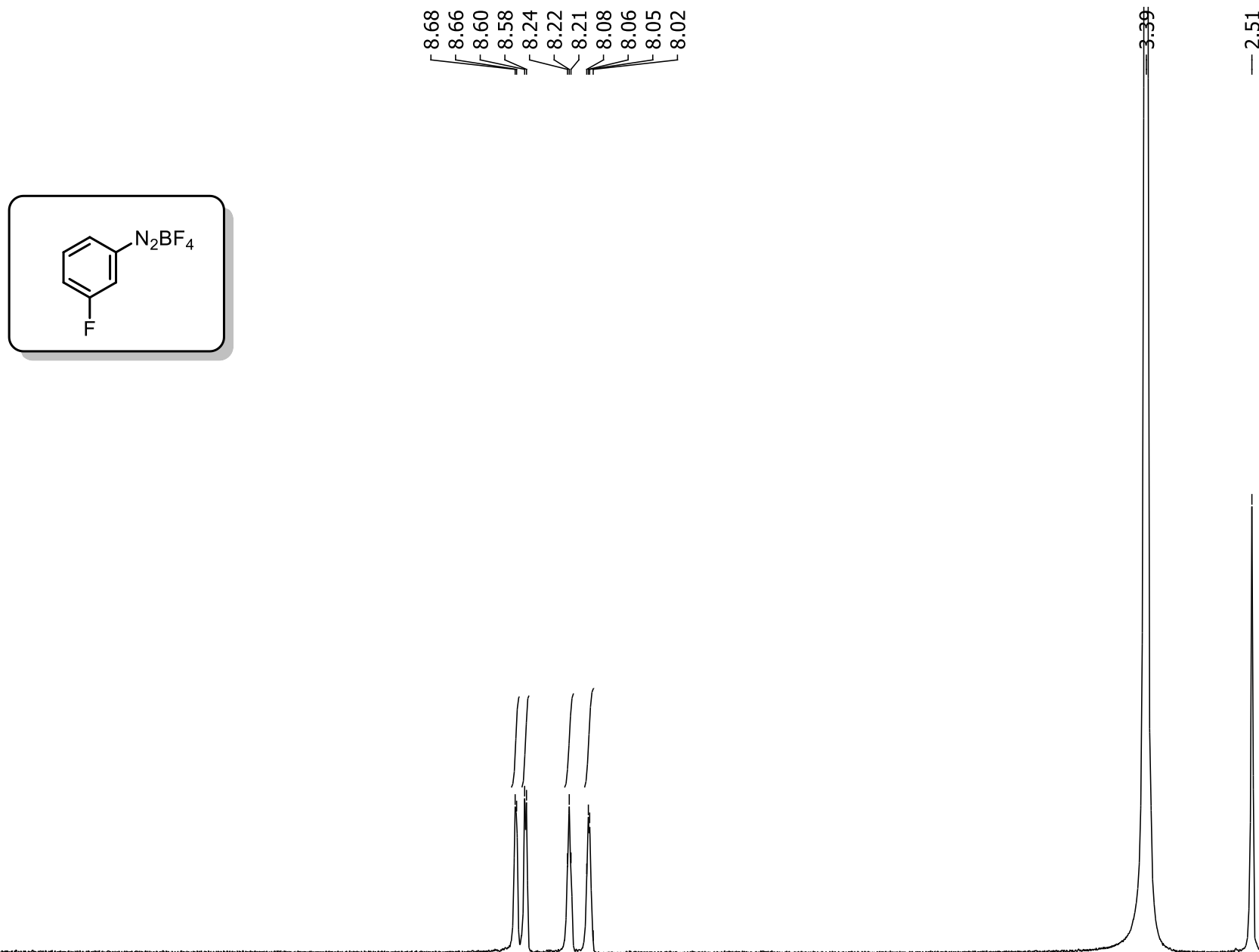

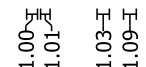

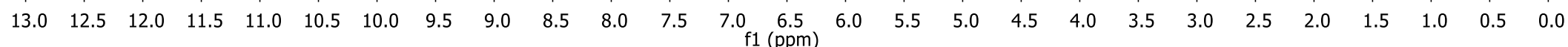


${ }^{1} \mathrm{H} \mathrm{NMR}\left(\mathrm{CDCl}_{3}, 500 \mathrm{MHz}\right)$ spectrum of 4-ethynylbenzenediazonium tetrafluoroborate (5f)

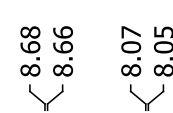

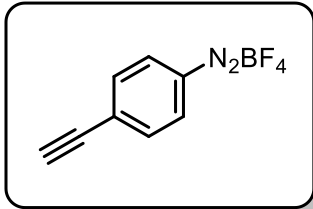

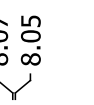
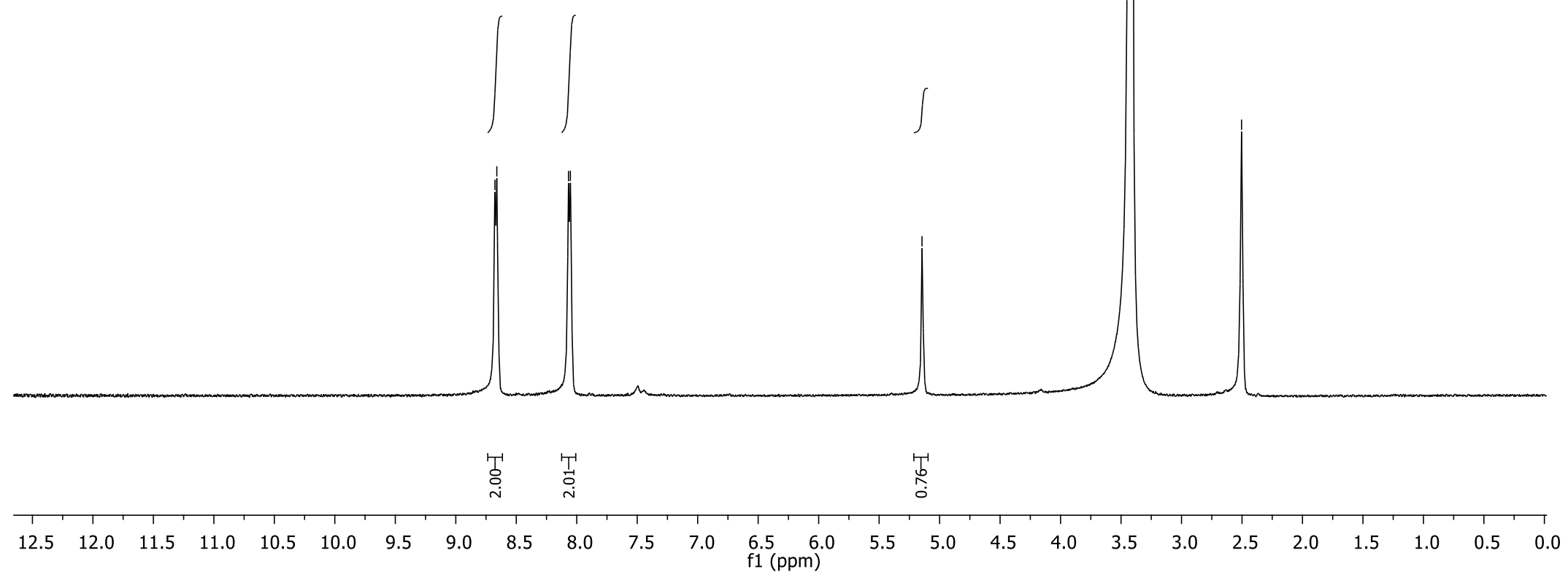
${ }^{1} \mathrm{H} \mathrm{NMR}\left(\mathrm{CDCl}_{3}, 500 \mathrm{MHz}\right)$ spectrum of 4-fluorobenzenediazonium tetrafluoroborate (5g)
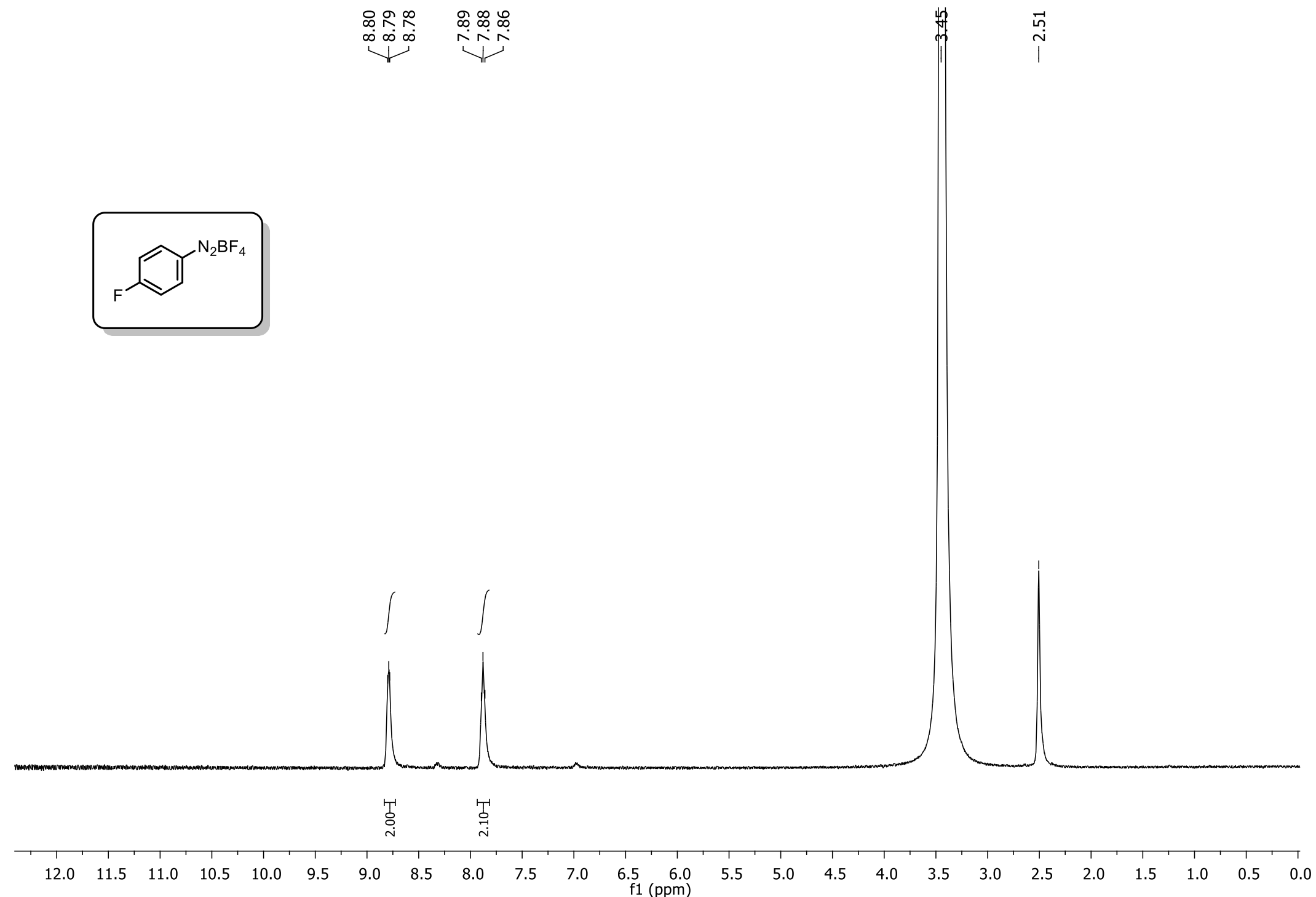
${ }^{1} \mathrm{H} \mathrm{NMR}\left(\mathrm{CDCl}_{3}, 500 \mathrm{MHz}\right)$ spectrum of 8-aminoquinoline (3a)
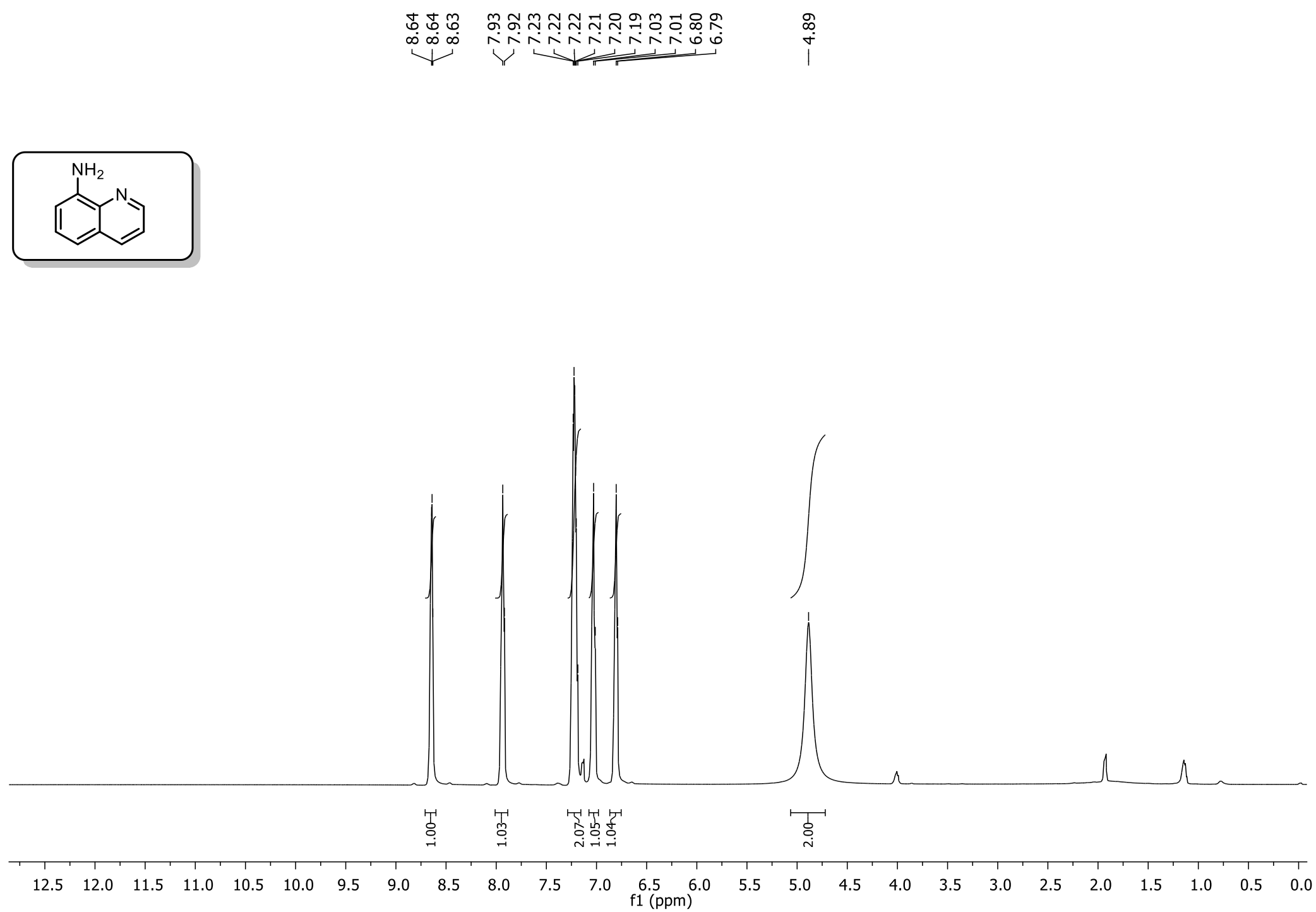
${ }^{1} \mathrm{H} \mathrm{NMR}\left(\mathrm{CDCl}_{3}, 500 \mathrm{MHz}\right)$ spectrum of (E)-5-((4-(tert-butyl)phenyl)diazenyl)quinolin-8-amine (6a)

$$
\text { mọ }
$$
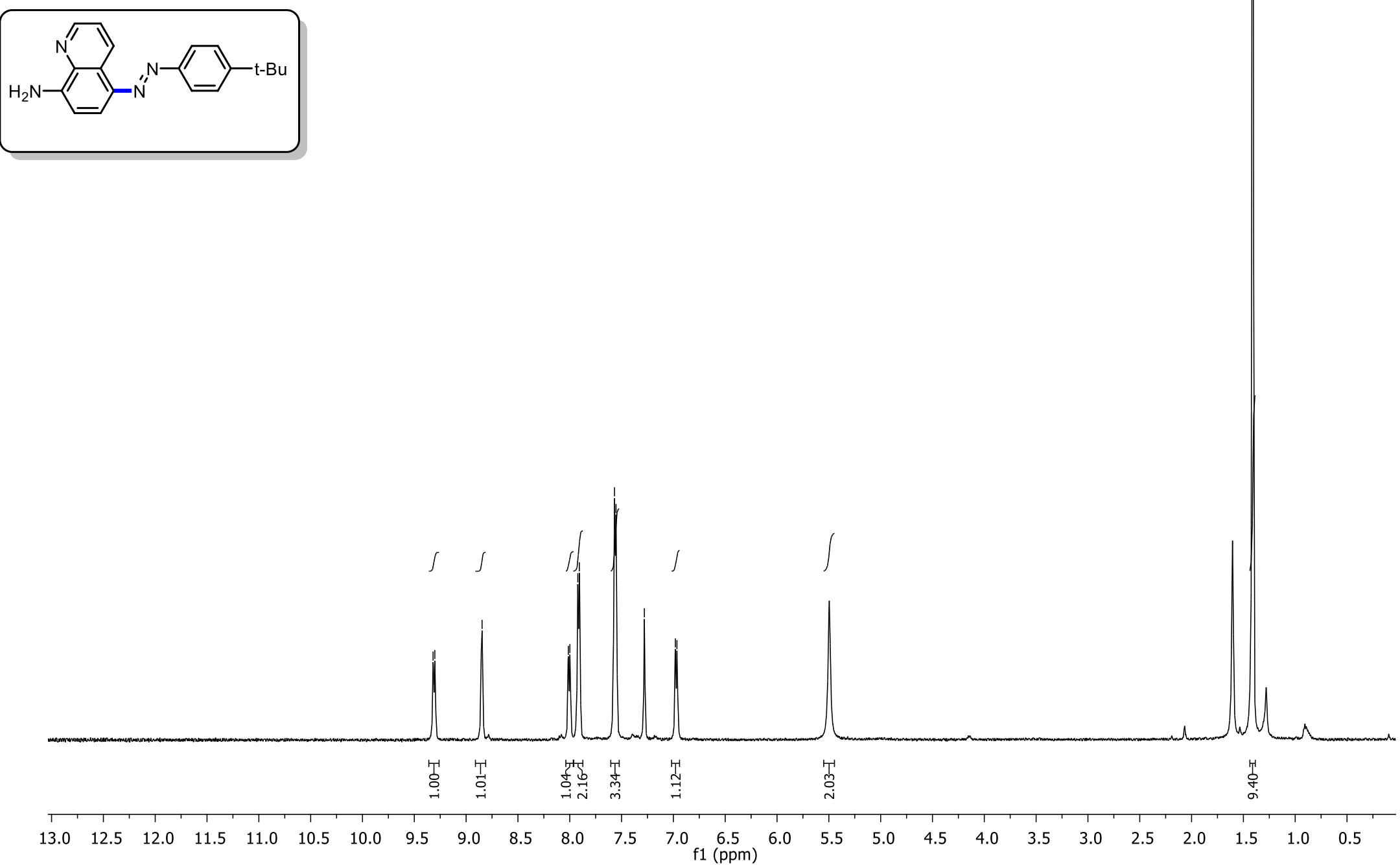
${ }^{13} \mathrm{C} \mathrm{NMR}\left(\mathrm{CDCl}_{3}, 126 \mathrm{MHz}\right)$ spectrum of (E)-5-((4-(tert-butyl)phenyl)diazenyl)quinolin-8-amine (6a)

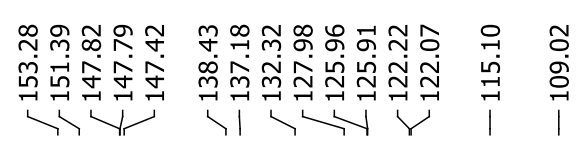

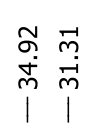
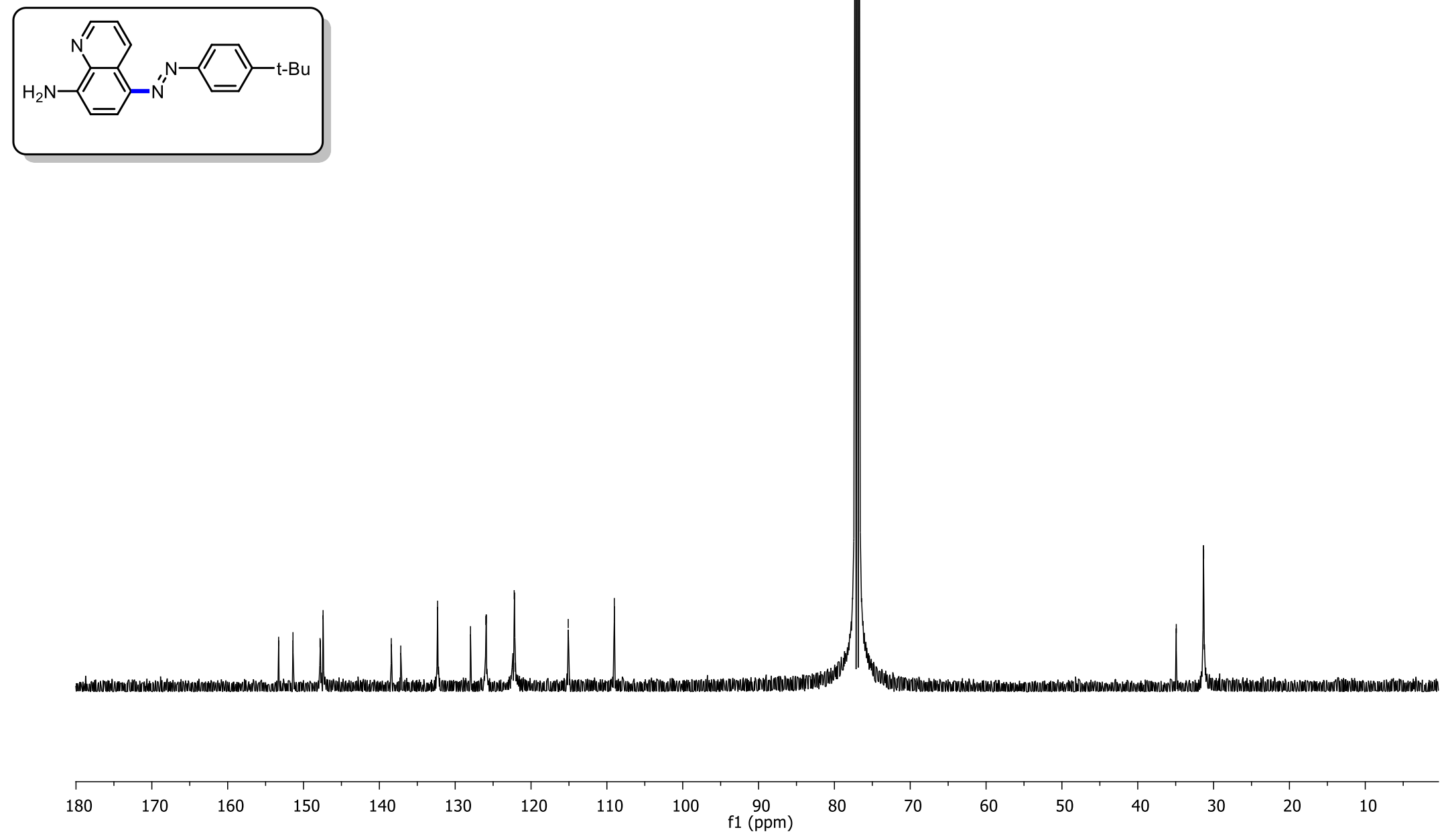
${ }^{1} \mathrm{H} \mathrm{NMR}\left(\mathrm{CDCl}_{3}, 500 \mathrm{MHz}\right)$ spectrum of (E)-5-((4-(trifluoromethyl)phenyl)diazenyl)quinolin-8-amine (6b)
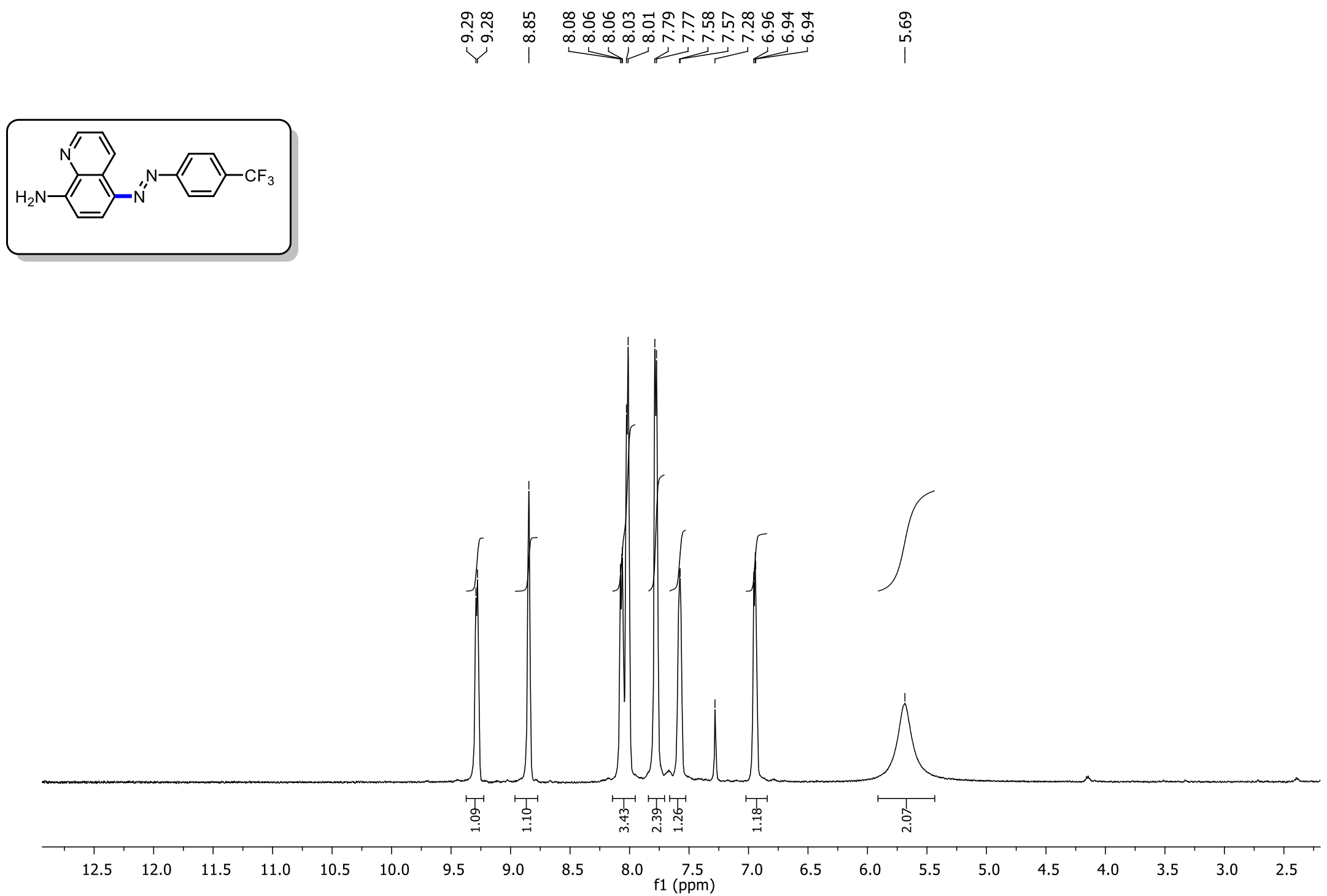
${ }^{13} \mathrm{C} \mathrm{NMR}\left(\mathrm{CDCl}_{3}, 126 \mathrm{MHz}\right)$ spectrum of (E)-5-((4-(trifluoromethyl)phenyl)diazenyl)quinolin-8-amine (6b)

$$
\text { lll }
$$
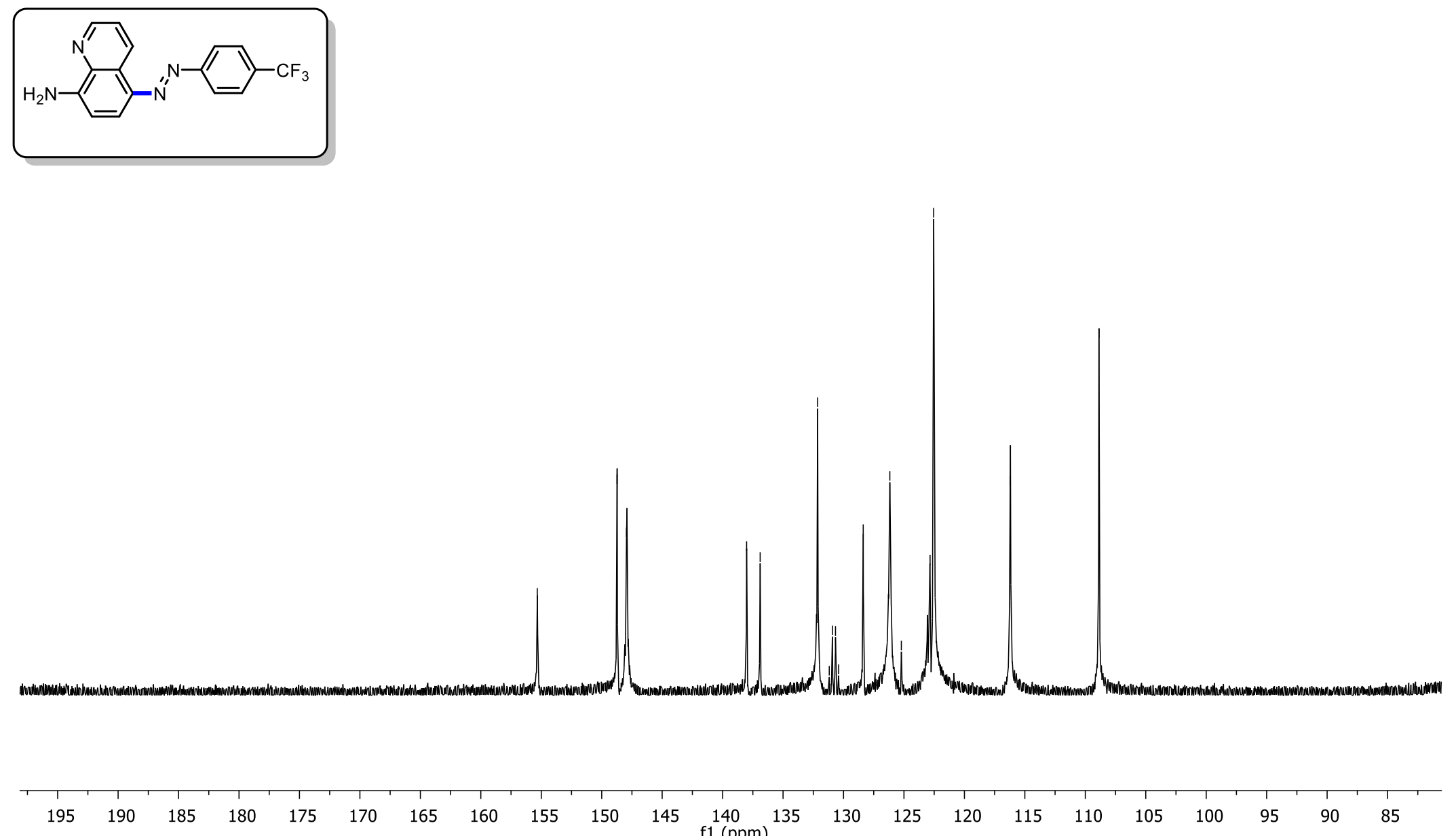
${ }^{1} \mathrm{H} \mathrm{NMR}\left(\mathrm{CDCl}_{3}, 500 \mathrm{MHz}\right)$ spectrum of (E)-5-((2-chlorophenyl)diazenyl)quinolin-8-amine (6c)
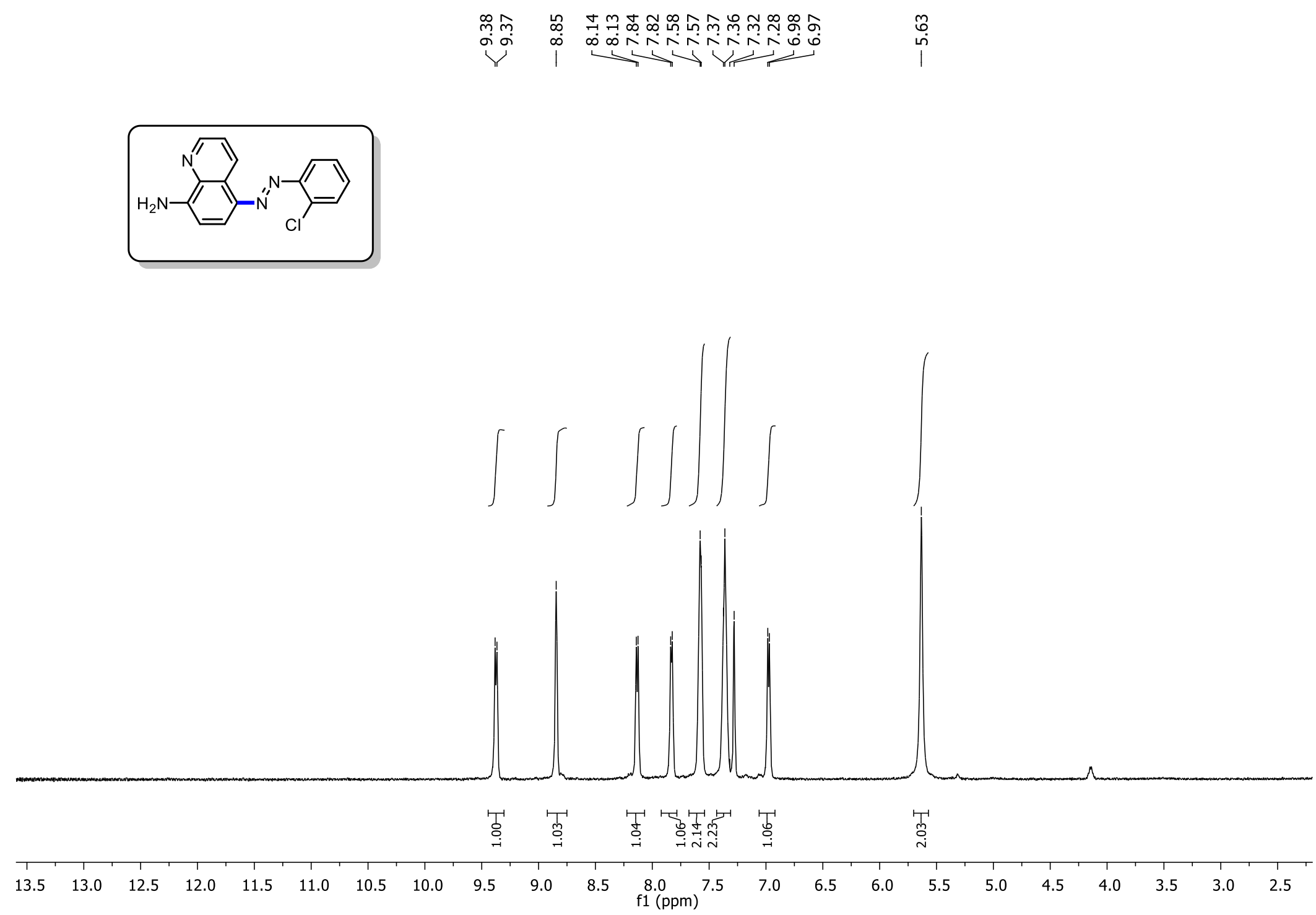


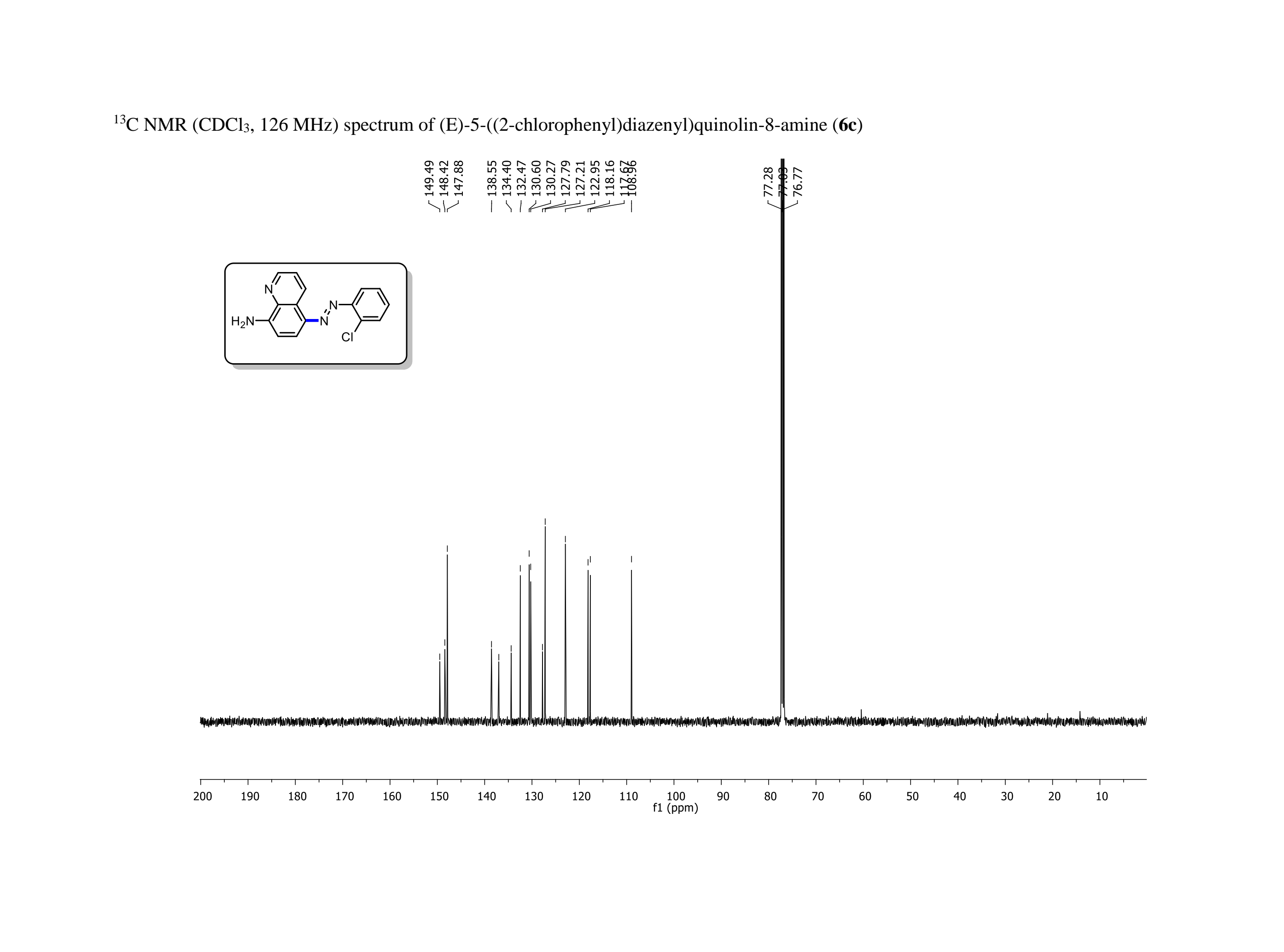


${ }^{1} \mathrm{H} \mathrm{NMR}\left(\mathrm{CDCl}_{3}, 500 \mathrm{MHz}\right)$ spectrum of (E)-5-((2-(trifluoromethyl)phenyl)diazenyl)quinolin-8-amine (6d)
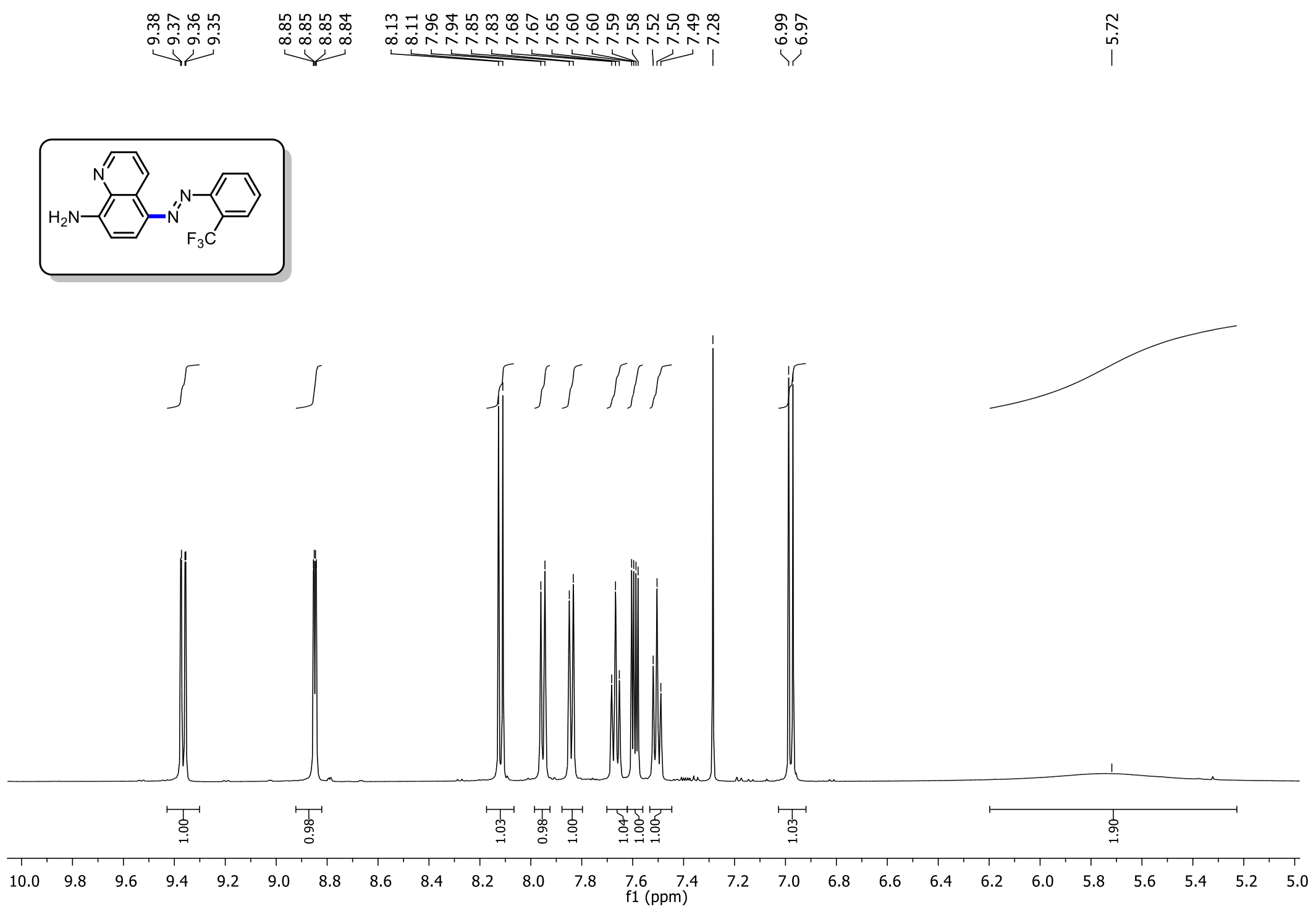
${ }^{13} \mathrm{C} \mathrm{NMR}\left(\mathrm{CDCl}_{3}, 126 \mathrm{MHz}\right)$ spectrum of (E)-5-((2-(trifluoromethyl)phenyl)diazenyl)quinolin-8-amine (6d)
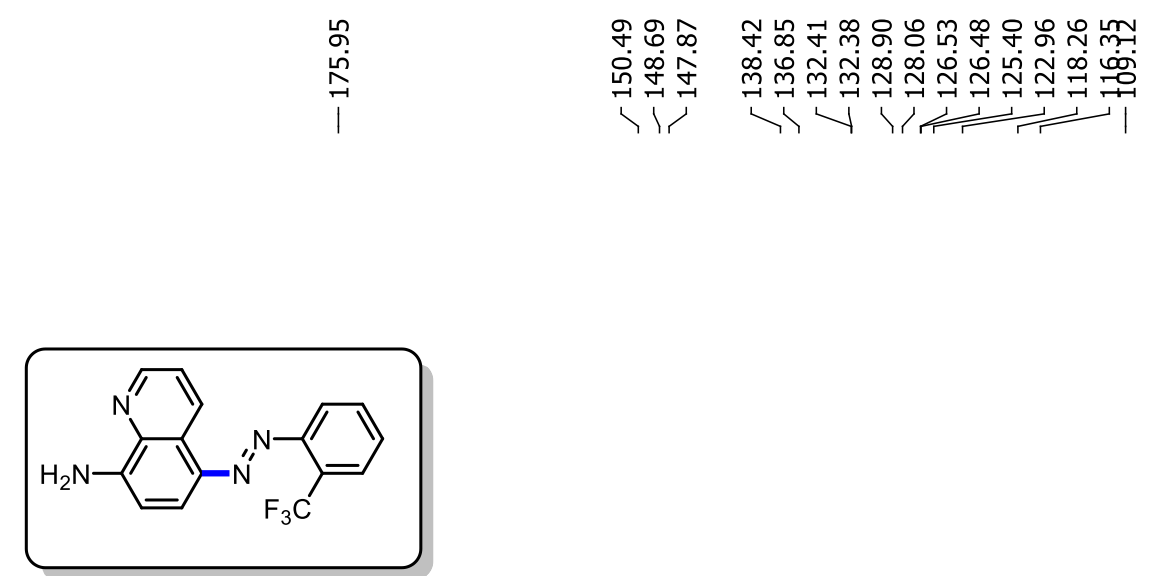

या रो ये
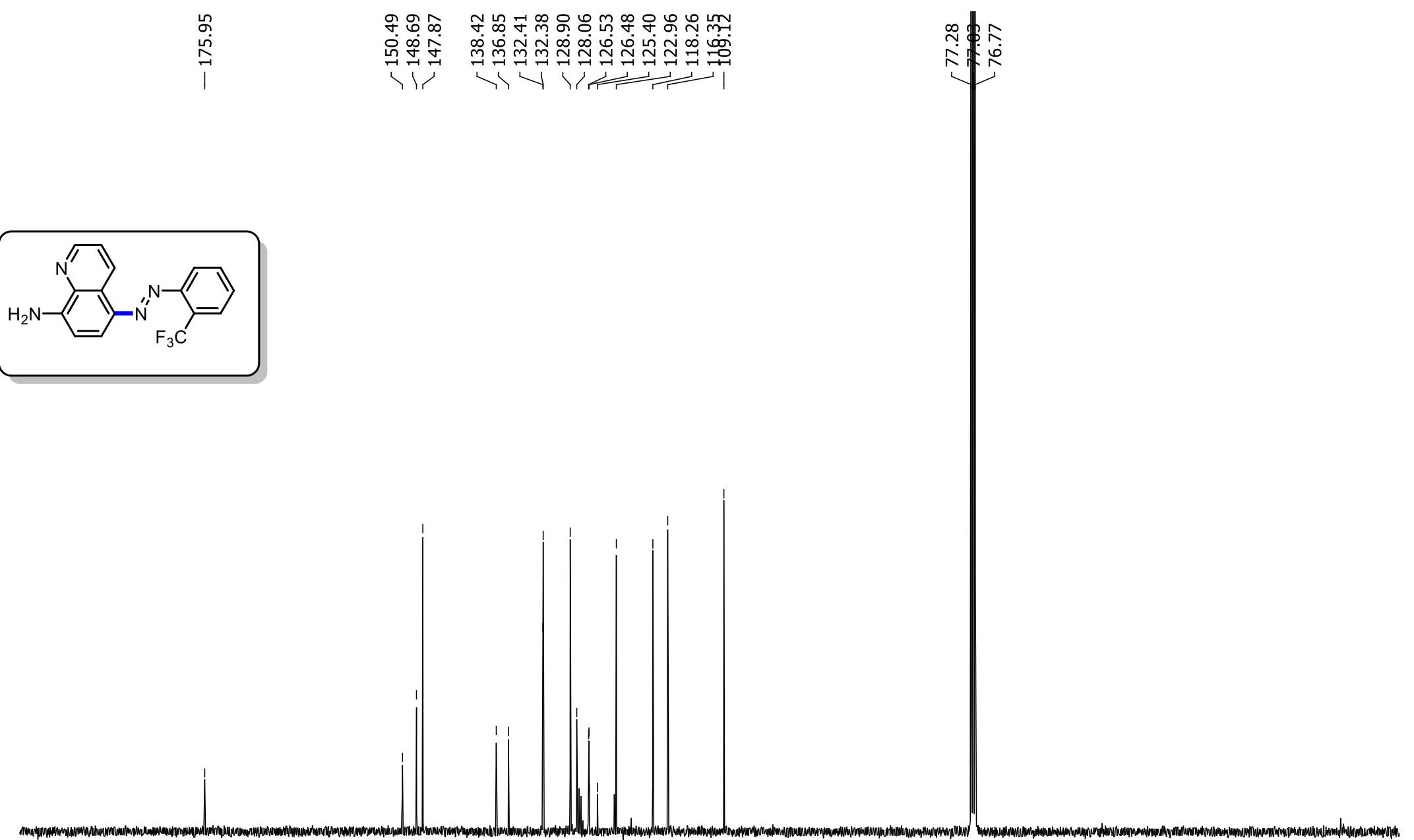

$190 \quad 180$ 
${ }^{1} \mathrm{H} \mathrm{NMR}\left(\mathrm{CDCl}_{3}, 500 \mathrm{MHz}\right)$ spectrum of (E)-5-((3-fluorophenyl)diazenyl)quinolin-8-amine (6e)
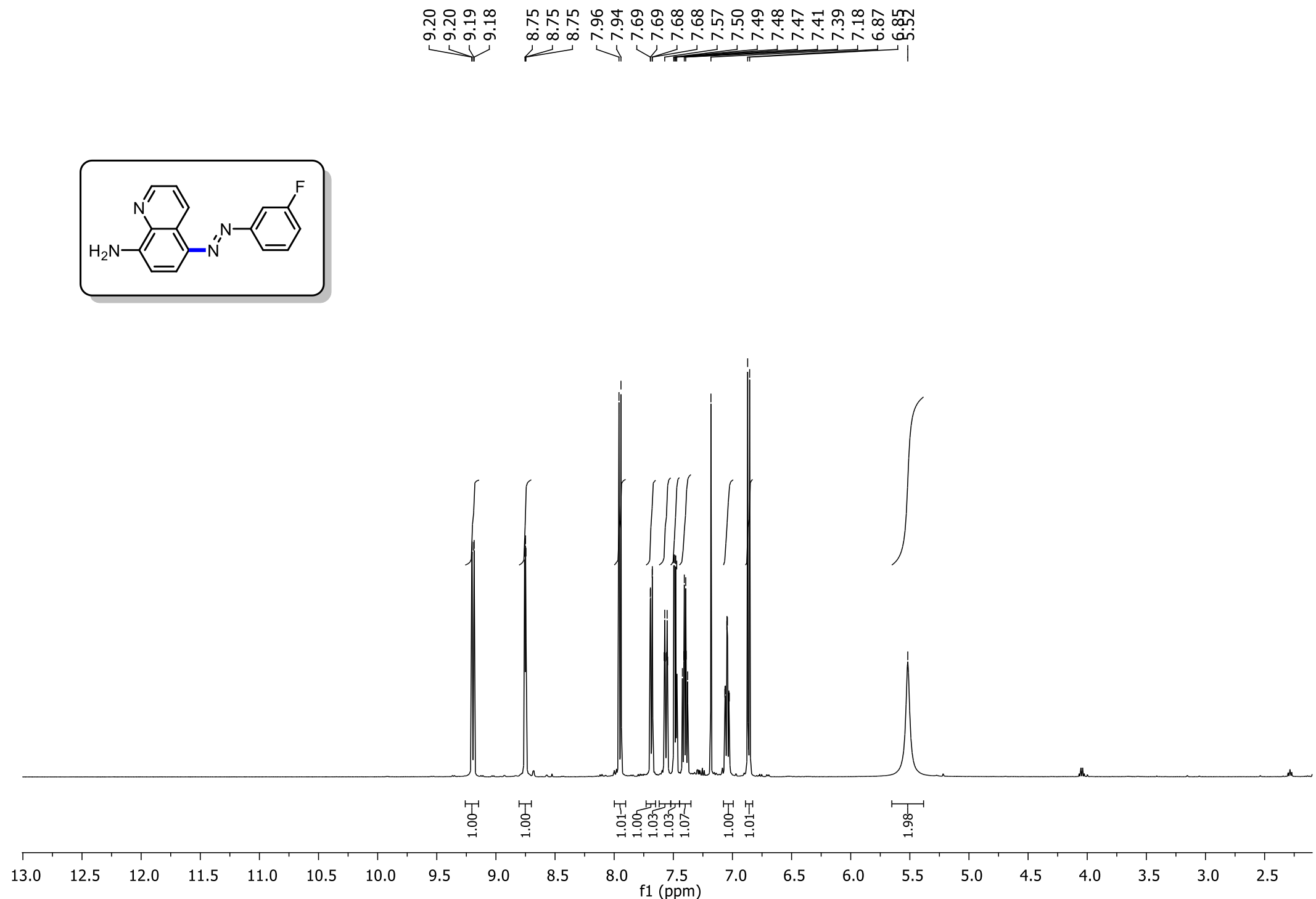
${ }^{13} \mathrm{C}$ NMR $\left(\mathrm{CDCl}_{3}, 126 \mathrm{MHz}\right)$ spectrum of (E)-5-((3-fluorophenyl)diazenyl)quinolin-8-amine (6e)
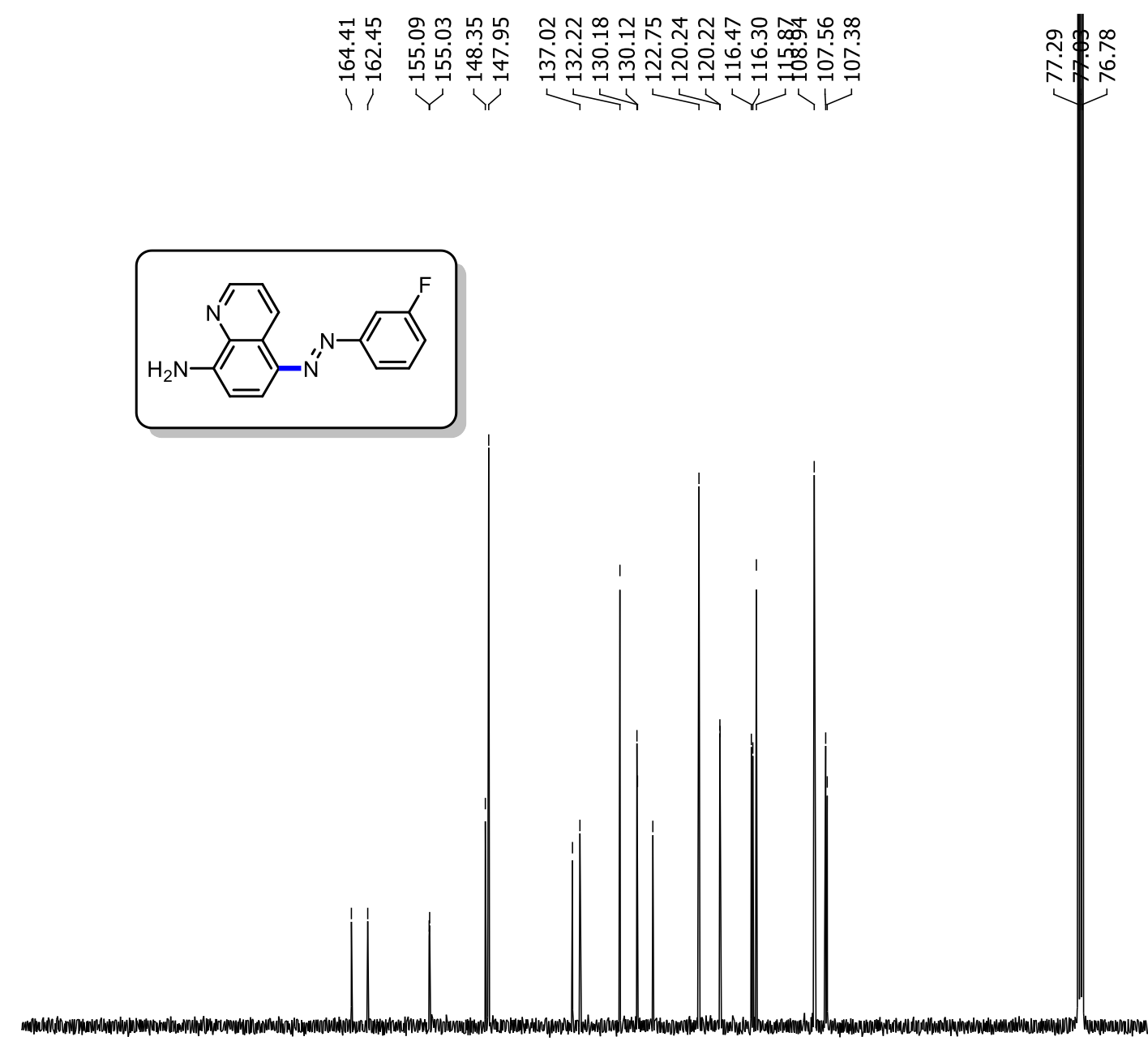

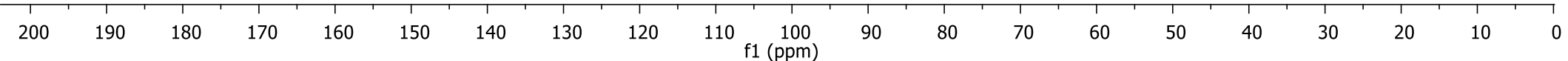


${ }^{1} \mathrm{H} \mathrm{NMR}\left(\mathrm{CDCl}_{3}, 500 \mathrm{MHz}\right)$ spectrum of (E)-5-((4-ethynylphenyl)diazenyl)quinolin-8-amine (6f)

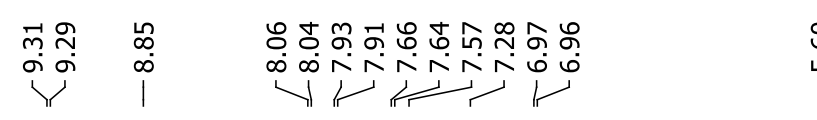
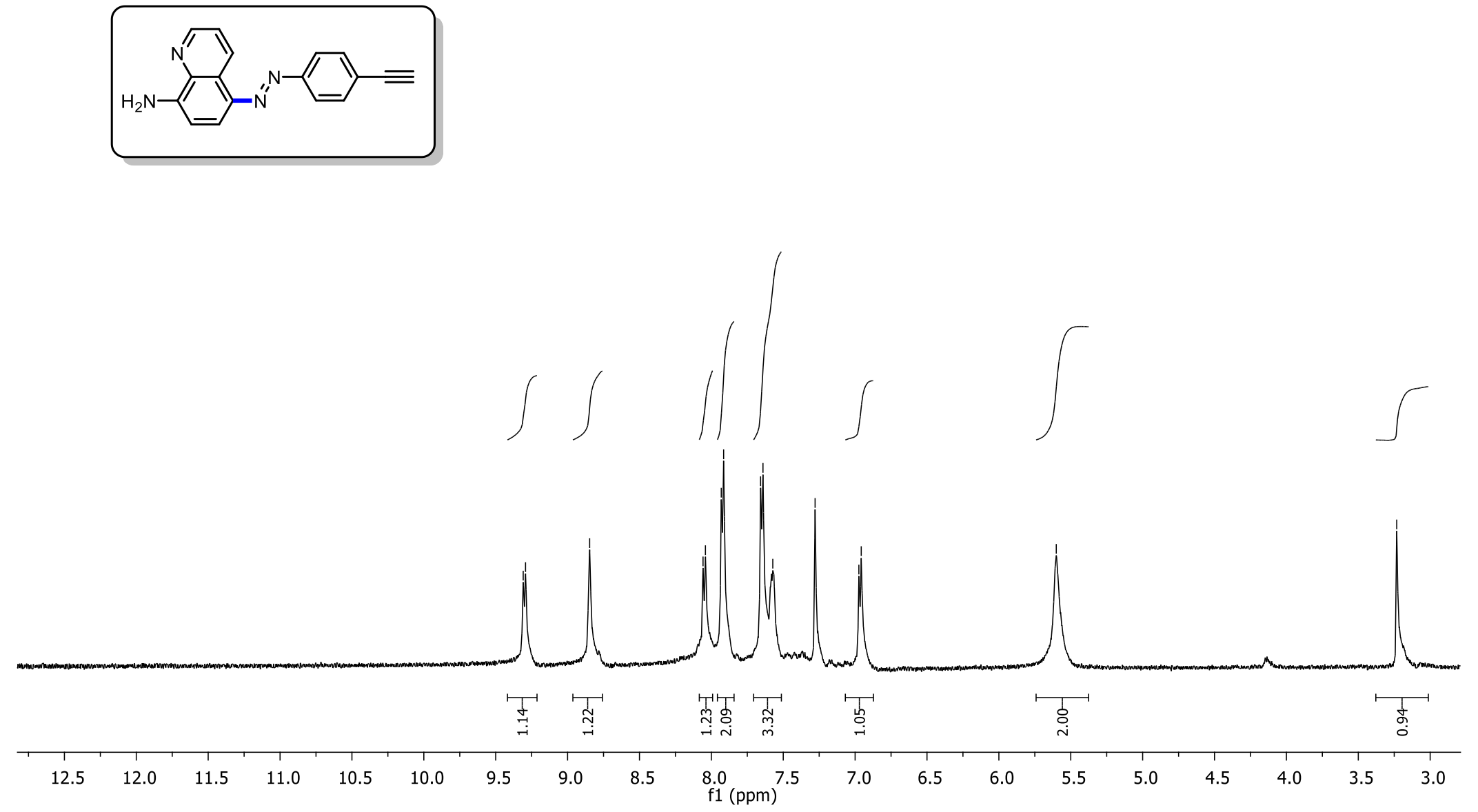
${ }^{13} \mathrm{C} \mathrm{NMR}\left(\mathrm{CDCl}_{3}, 126 \mathrm{MHz}\right)$ spectrum of (E)-5-((4-ethynylphenyl)diazenyl)quinolin-8-amine (6f)

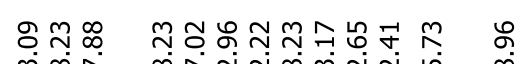

$$
\begin{aligned}
& \text { 岱守离 } \\
& \text { ।रे रोरा।रा। }
\end{aligned}
$$
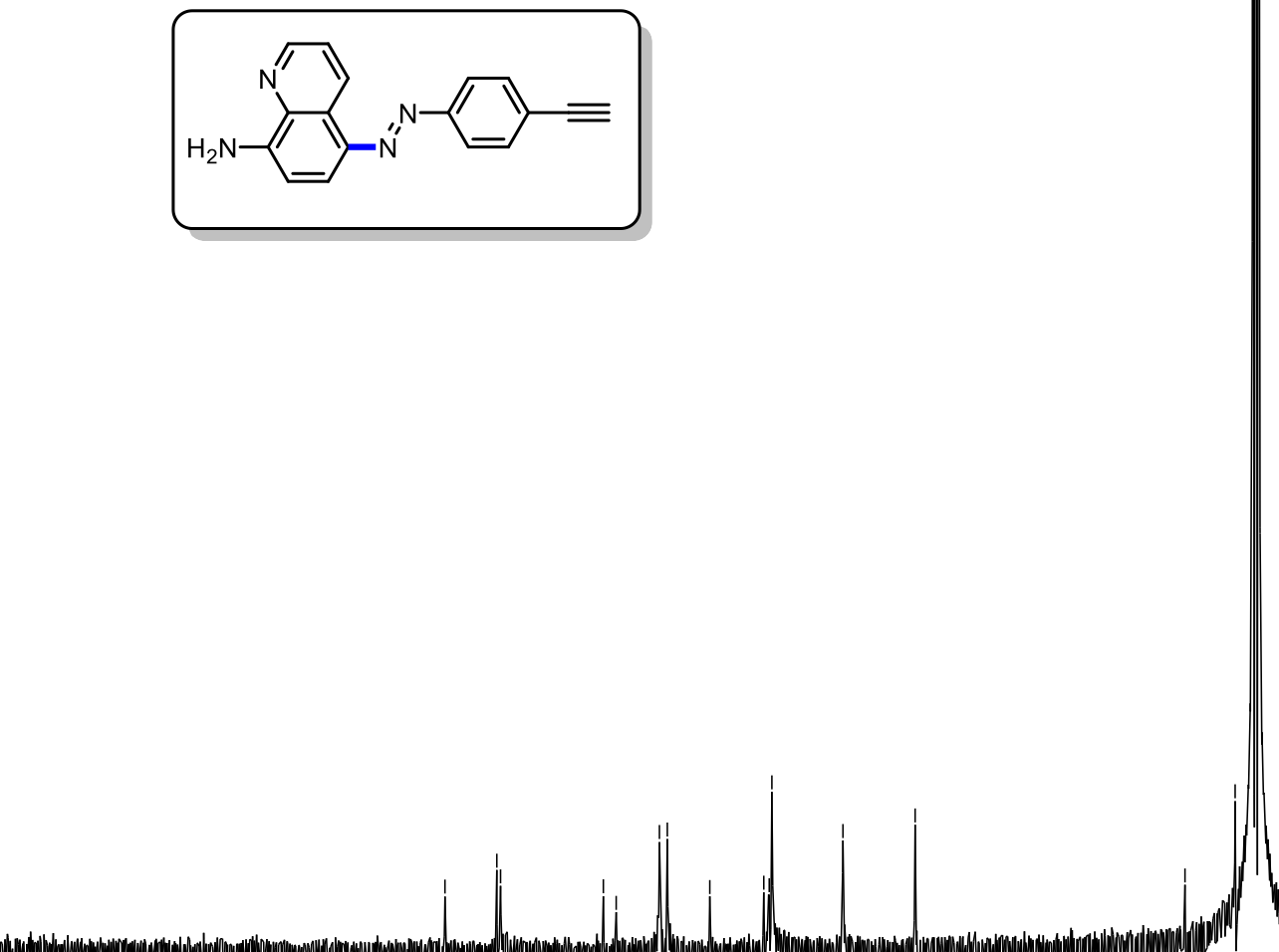
${ }^{1} \mathrm{H} \mathrm{NMR}\left(\mathrm{CDCl}_{3}, 500 \mathrm{MHz}\right)$ spectrum of (E)-5-((4-fluorophenyl)diazenyl)quinolin-8-amine (6g)

$$
\text { Via }
$$
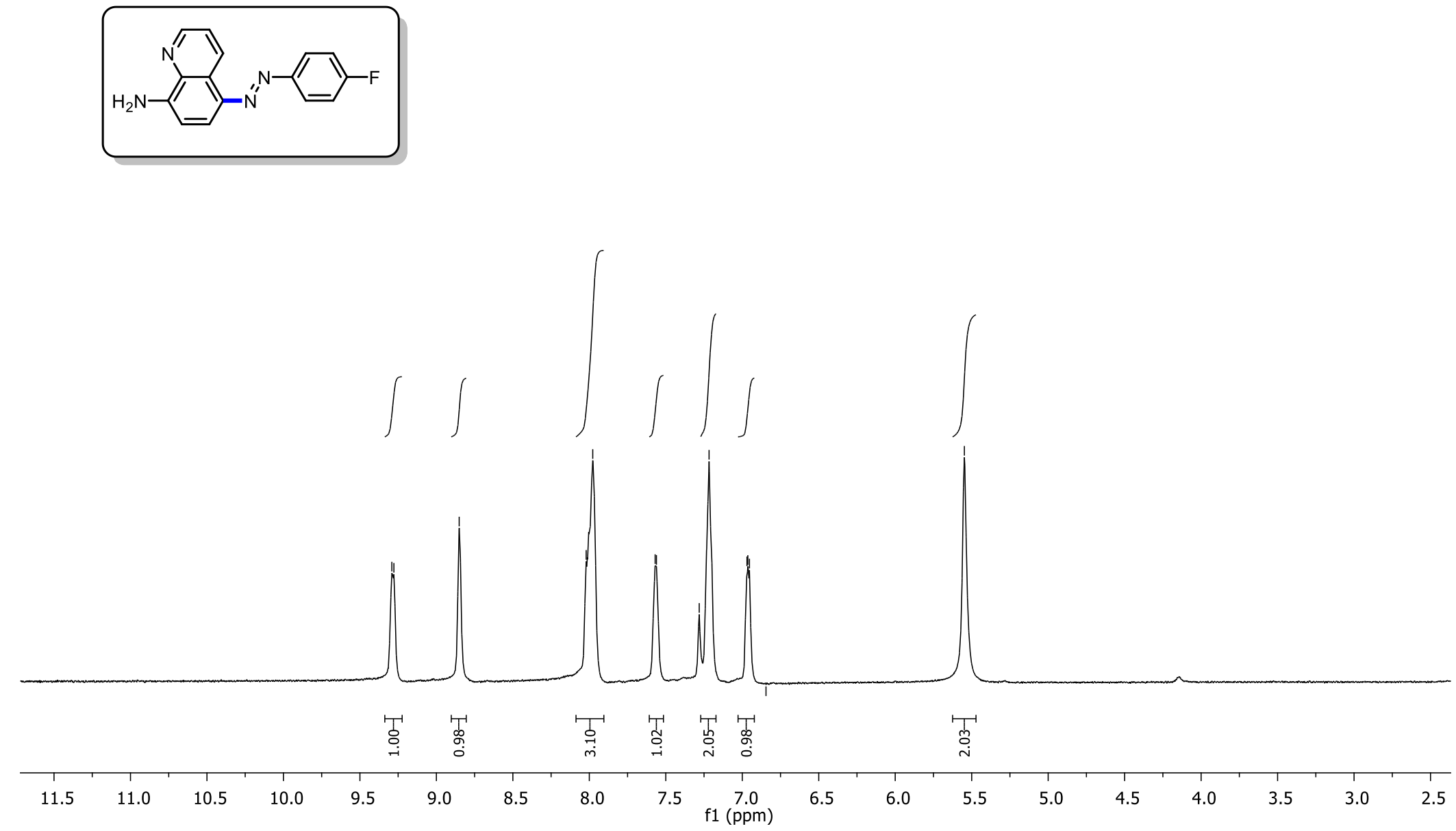
${ }^{13} \mathrm{C} \mathrm{NMR}\left(\mathrm{CDCl}_{3}, 126 \mathrm{MHz}\right)$ spectrum of (E)-5-((4-fluorophenyl)diazenyl)quinolin-8-amine (6g)
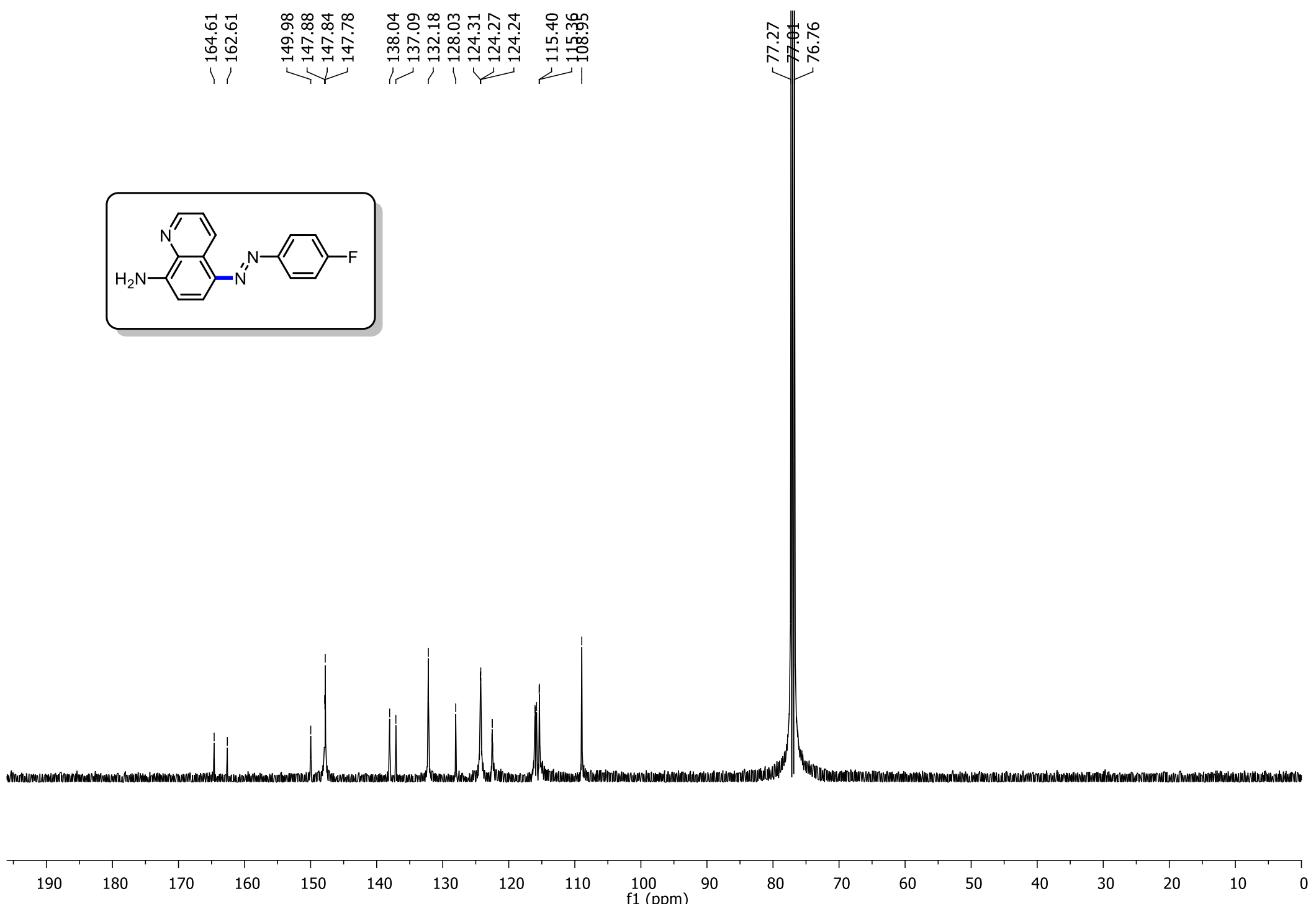